\title{
WestVirginiaUniversity
}

THE RESEARCH REPOSITORY @ WVU

West Virginia Agricultural and Forestry Experiment

Davis College of Agriculture, Natural Resources

Station Bulletins

And Design

$1-1-1937$

\section{West Virginia pastures : type of vegetation, carrying capacity, and soil properties}

W.H. Pierre

Follow this and additional works at: https://researchrepository.wvu.edu/ wv_agricultural_and_forestry_experiment_station_bulletins

\section{Digital Commons Citation}

Pierre, W. H., "West Virginia pastures : type of vegetation, carrying capacity, and soil properties" (1937). West Virginia Agricultural and Forestry Experiment Station Bulletins. 280.

https://researchrepository.wvu.edu/wv_agricultural_and_forestry_experiment_station_bulletins/281 @ WVU. It has been accepted for inclusion in West Virginia Agricultural and Forestry Experiment Station Bulletins by an authorized administrator of The Research Repository @ WVU. For more information, please contact ian.harmon@mail.wvu.edu. 


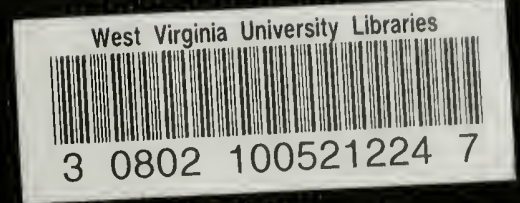





\section{West Virginia Pastures:}

\section{Type of Vegetation, Carrying Capacity, and Soil Properties}

W. H. PIERRE and J. H. LONGWELL

West Virginia Agricultural Experiment Station

R. R. ROBINSON

Division of Forage Crops and Diseases, Bureau of Plant Industry, U. S. D. A.

G. M. BROWNING, IVAN MCKEEVER, and R. F. COPPLE

Soil Conservation Service, U. S. D. A.

West Virginia Agricultural Experiment Station, Morgantown F. D. Fromme, Director

In Cooperation with the Bureau of Plant Industry and with the Soil Conservation Service of the United States Department of Agriculture 


\section{Contents}

\section{INTRODUCTION}

Pasture Situation _.

Objectives of Study _._.

GENERAL PLAN AND PROCEDURE _._. GENERAL INFORMATION REGARDING PASTURE AREAS

Location of Areas _... 7

Climate _...

Soils -

Pastures in Relation to Other Land in Farms _._._._._._. 12

Kind of Animals Pastured _. 17

THE CARRYING CAPACITY OF PASTURES _.

TYPE OF VEGETATION IN OPEN PASTURES

Desirable Species _-_._- 22

Undesirable Species and Bare Space _._._. 23

PASTURE MANAGEMENT _.

SOIL CONDITIONS IN THE DIFFERENT AREAS

Soil Acidity and Lime Requirement _._. 28

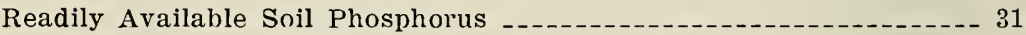

Soil Erosion _-_... 33

Slope -

Pasture Areas Not Suitable for Improvement _._._._._. 36

COMPARISON OF DIFFERENT AREAS _.

PASTURE CONDITIONS AS RELATED TO SOIL TYPE _............. 42

GENERAL RELATIONSHIPS

Relation Between Type of Vegetation and Carrying Capacity _....... 44

Relation Between Type of Pasture and Acidity and Available Phosphorus Content of Soil

GENERAL CONCLUSIONS AND RECOMMENDATIONS _._.

APPENDIX _-

ABSTRACT 


\title{
West Virginia Pastures: Type of Vegetation, Carrying Capacity, and Soil Properties
}

\author{
by
}

\author{
W. H. PIERIRE and J. H. LONGWELL \\ West Virginia Agricultural Experiment Station
}

R. R. ROBINSON ${ }^{1}$

Division of Forage Crops and Diseases

Bureau of Plant Industry, United States Department of Agriculture

G. M. BROWNING ${ }^{2}$, IVAN McKEEVER ${ }^{1}$, and R. F. COPPLE

Soil Conservation Service, United States Department of Agriculture

\section{Introduction}

$\mathrm{T}$

HE PERMANENT Pastures of Wrst Virginia form one of the state's chief sources of agricultural wealth. According to the 1935 census there is approximately twice as much non-woodland pasture in the state as harvested crop land. The reason for this large pasture acreage is easily understood. Much of the land in farms is so rolling that it cannot be used for tilled crops without serious loss from soil erosion. On the other hand, good permanent pastures can be maintained on rolling to fairly steep soils. Not only do pastures offer an excellent means of controlling erosion and maintaining soil fertility on such soils, but good pastures furnish the cheapest livestock feed produced on the farm. It is a well-known fact that much of the profit derived from the important livestock industry of the state is made while the animals are on pasture. With greater emphasis being placed both on efficient production and on the control of soil erosion, it is evident that pastures should occupy an increasingly important place in West Virginia agriculture.

During the past ten to fifteen years many West Virginia farmers have observed a declease in the carrying capacity of theil pastures. General observations have also indicated that in many sections of the state good bluegrass pastures are relatively scarce. Very little definite information has been available, however, on the extent to which bluegrass and clover have been replaced by poor native grasses and weeds in the pastures of different sections of the state. Experimental work conducted during the past fourteen years at this Station shows that one of the important causes for poor pastures is depleted soil fertility. Lime and superphosphate have been found to bring back bluegrass and clover on poor pastures and to double the herbage yields. * Information is lack-

${ }^{1}$ Assistant Agronomist.

${ }^{2}$ Associate Soil Conservationist.

3 Associate Agronomist.

* Results of fertiljzer experiments conducted since 1930 are soon to be published in a bulletin of the West Virginia Agricultural Experiment Station. Results of earlier experiments have been published in Bulletins 177 and 235. 
ing, however, on the defieiencies of phosphorus and lime in the pasture soils of different sections of the state. Moreover, very little study has been given to such factors as soil crosion and various management practices in determining the present productivity of pastures and the possibility of improving them.

In an effort to obtain more definite information on these various questions, a cooperative study was started in the summer of 1935 by the Agricultural Experiment Station in cooperation with the Bureau of Plant Industry and the Soil Conservation Service of the United States Department of Agriculture.

The main objectives of this study may be listed as follows:

(1) To obtain information regarding pasture management and the carrying capacity of permanent pastures in different sections of the state.

(2) To determine the type of vegetation of permanent pastures and to study the relationship between the kind of vegetation and the carrying capacity of pastures.

(3) To determine the acidity and lime requirement of pasture soils as well as their content of readily available phosphorus, their slope, and the extent of soil erosion.

(4) To determine the soil factors primarily responsible for the poor type of vegetation and low carrying capacity of various pastures, and to estimate on the basis of these data the percentage of the permanent pasture area that is probably not worth improving.

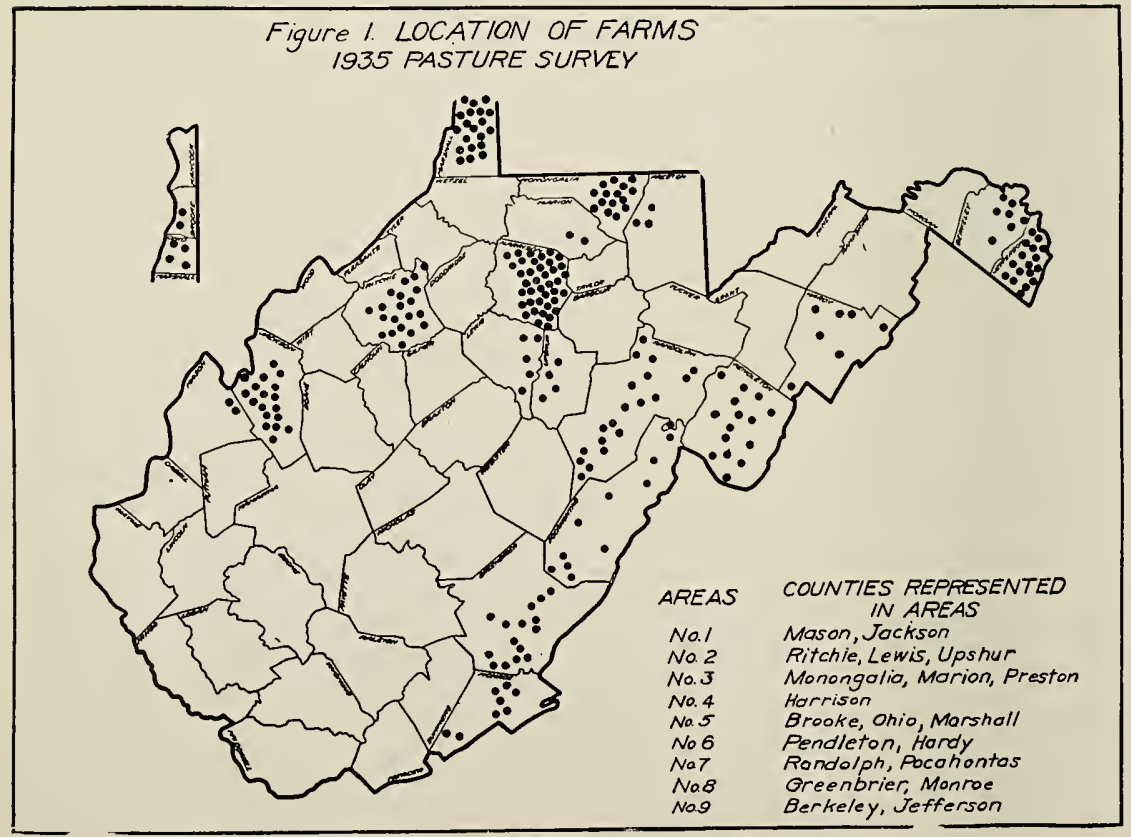




\section{General Plan and Procedure}

Nine areas in different parts of West Virginia were chosen for the study. A minimum of 20 farms was studied in each area, the total number of farms being 232 (Fig. 1). The farms were selected at randon so as to assure good representation of different parts of the area. In. most eases the selection was made from a large list of farms furnisher either by the county agent or by the Agricultural Extension Service. In Area 3 (Monongalia, Marion, and Preston counties), however, it seemed desirable to study only the dairy farms; consequently these were selected from a list of the dairy farms of this area. Farms too small to be eonsidered typical were not studied.

The field study consisted of two parts: (1) making a detailed study of each pasture on the farm with particular reference to the kind of regetation, the slope of the land, and the soil properties, and (2) obtaining data from the farmer regarding the earrying eapacity of the pasture, age and treatment of pastures, pasture management, and other related information. A total of 775 pastures was studied in the different areas.

Careful estimates were made in each pasture of the portion of the ground that was unoceupied and that covered by Kentueky bluegrass, white clover, and other desirable species as compared with that occupied by poor native grasses and weeds. Where the pasture regetation was quite different in various parts of a pasture, each part was considered by itself, and a separate estimate and report made.

In studying the soil of each pasture a record was made not only of the soil type or types, but also of the slope and the amount of erosion that had taken place as shown by the depth of the surface soil and the presence of gullies. In addition, soil samples to a depth of three inches were taken from small areas selected as representative either of the pasture as a whole or of local areas in the pasture. A separate botanical analysis or record of the type of vegetation was made for each of the areas from which samples were taken. This was done in an effort to determine as accurately as possible the relation between the type of vegetation and the chemical properties of the soil.

The field work was done by three parties of two men each. As shown in Table 1, most of the field work was completed during June and early July, when the late as well as the early growing plant speeies are present and before the usual dry summer period oceurs. The main exceptions were Areas 6 and 7 which were studied during the latter part of Julr. The latter of these areas, however, is situated in a region of high elevation where the season is an average of two to three weeks later than in most of the other areas studied. The confining of the field study to this relatively short period tended to minimize any discrepancies in botanical analysis due to seasonal variation and thus made the data for the different areas more strictly comparable. In order to assure uniformity among the different parties, particularly with reference to making estimates of botanical analysis, the leaders of each party worked together in Area 4 during the first week. Thereafter the parties worked 
mostly in different areas, as shown in Table 1, but the work was colrelated from time to time in an effor't to eliminate any discrepancies or lack of uniformity that might develop among the parties.

Printed data sheets were used to record the different types of datin obtained. Two sheets were used to record pasture management and other' general information, one sieet to record the soil data and botanical analysis of each pasture, one sheet to record soil data and botanical analysis for each soil sample taken, and one shect on which to sketel: a diagram of the farm, showing topography and erosion data for each pasture and also the location of the soil samples that were taken. An Abney level was used in estimating the degree of slope of the pasture.

The laboratory studies consisted primarily in determining the lime needs of the soil, as shown by the pH values. and the contents of readily available phosphorus. The glass eleetrode was used in determining the pII ralues of the soil; and Truog's laboratory method for readily arail-

Table 1 -Scope and dates of field stuay

\begin{tabular}{|c|c|c|c|c|c|c|}
\hline $\begin{array}{l}\text { Area } \\
\text { No. }\end{array}$ & $\begin{array}{c}\text { Counties } \\
\text { in } \\
\text { areat } \\
\end{array}$ & $\begin{array}{l}\text { Num- } \\
\text { ber of } \\
\text { farmis } \\
\text { studied }\end{array}$ & $\begin{array}{c}\text { Num- } \\
\text { ber of } \\
\text { pas- } \\
\text { tures } \\
\text { studied }\end{array}$ & $\begin{array}{c}\text { Total } \\
\text { acres } \\
\text { in pas- } \\
\text { tures } \\
\text { studied }\end{array}$ & $\begin{array}{c}\text { Dates of } \\
\text { field } \\
\text { study }\end{array}$ & $\begin{array}{l}\text { Field } \\
\text { pinty }\end{array}$ \\
\hline 1 & $\begin{array}{l}\text { Jackson } \\
\text { Mason }\end{array}$ & 20 & 72 & 2220 & $\tau / 9$ to $7 / 20$ & A \\
\hline 2 & $\begin{array}{l}\text { Ritchie } \\
\text { TLewis } \\
\text { Lpsliur }\end{array}$ & 29 & 82 & 4047 & $\begin{array}{l}6 / 17 \text { to } 7 / 3 * \\
7 / 15 \text { to } 7 / 19\end{array}$ & $A, B$ \\
\hline 3 & $\begin{array}{l}\text { Monongalia } \\
\text { Marion } \\
\text { Preston }\end{array}$ & 20 & $4 S$ & $165 \mathrm{~S}$ & $6 / 3$ to $6 / 14$ & $\alpha$ \\
\hline 4 & Harrison & 39 & 125 & 4879 & $5 / 22$ to $6 / 21$ & $\mathrm{~A}, \mathrm{~B}, \mathrm{C}$ \\
\hline 5 & $\begin{array}{l}\text { Marshall } \\
\text { Ohio } \\
\text { Broke }\end{array}$ & 26 & 123 & 2414 & $6 / 25$ to $7 / 12$ & $\mathrm{~B}$ \\
\hline 6 & $\begin{array}{l}\text { Pendleton } \\
\text { Hardy }\end{array}$ & 20 & $\$ 3$ & $4 \$ 26$ & $7 / 23$ to $S / 2$ & $\mathrm{~B} \& \mathrm{C}$ \\
\hline 7 & $\begin{array}{l}\text { Randolph } \\
\text { Pocaholtas }\end{array}$ & 81 & 88 & 7396 & $7 / 14$ to $\mathrm{s} / 2$ & $A \& C$ \\
\hline 3 & $\begin{array}{l}\text { Greenbrier } \\
\text { Monroe }\end{array}$ & 23 & $\$ 1$ & 3220 & $6 / 24$ to $7 / 12$ & C \\
\hline 9 & $\begin{array}{l}\text { Jefferson } \\
\text { Berkeley }\end{array}$ & 24 & 72 & 1280 & $6 / 4$ to $6 / 21$ & $\mathrm{C}$ \\
\hline \multicolumn{2}{|c|}{ Total } & 232 & 775 & 31,940 & $5 / 22$ to $s / 2$ & \\
\hline
\end{tabular}

* Ritchie county pastures were studied between June 17 and July 3 by rarty $A$, and the remainder of the area by party $B$ on July 15 to 19 , inclusive.

+ Since in Areas 1, 2, 3, and 5 most of the farms were situated in one county, the area will be referred to in succeding tables by the name of that county. 
able phosphorus." A limited number of soil samples were also studied for total exchangeable bases and percentage base saturation.

In addition to the field and laboratory studies this report also includes some pertinent data obtained from census**; and climatological reports. $\dagger$

\section{General Information Regarding Areas}

\section{Location of Areas}

The location of the nine general areas selected for this study, as well as the location of the individual farms, is shown in Figure 1. These areas represent most of the important pasture sections of the state and many of the important soil and climatic conditions. In all areas but one, parts of at least two counties are included. $\dagger$ Most areas are representative not only of the particular section of the county or counties shown in Figure 1, but also of sections in the same or other counties similar in soil type and in other general conditions. In some cases, however, the areas are typical only of the parts of the counties shown by the location of the farms (Fig. 1). Thus Area 9 represents only the limestone section of Jefferson and Berkeley counties, and Area 8 represents only the limestone section of Monroe and Greenbrier counties.

\section{Climate}

The climate of West Virginia varies considerably in different parts of the state. This is due primarily to the wide variation in altitude and to a lesser extent to differences in latitude. The average elevation of the farms in the different areas varies from less than 500 feet for the Jefferson-Berkeley county area to approximately 2,600 feet for the Randolph-Pocahontas county area (Table 2). The average summer temperature (April to September inclusive) varies from $61.6^{\circ} \mathrm{F}$. to $67.3^{\circ}$ F., and the summer rainfall (April to September inclusive) from 17.8 inches to 27.7 inches. The highest summer and annual rainfall oceurs at the high elevations in the Randolph-Pocahontas county area, whereas the area of lowest rainfall is in the lower altitudes of Pendleton and Hardy counties. The low rainfall in the latter counties is probably explained by the fact that this area lies just east of the high part of the Allegheny mountains. Outside of this section the areas of lowest rainfall coincide fairly well with the areas of lowest elevation.

The rainfall is fairly well distributed throughout the year, the months of highest rainfall for the state being July (4.57 inches), June (4.37 inches), and August (4.08 inches). Nevertheless, pastures usually

*Truog, Emil. The determination of the readily available phosphorus of soils. Jour. Amer. Soc. Agron. 22: 874-8\$2, 1930.

**U. S. Census of Agriculture, 1935.

Climatological Data, W. Va. Section, U. S. Department of Agriculture Weather Bureau, Vol. 43 , No. $13,1935$.

$\dagger+$ Since in some areas most of the farms were situated in one county, the area will be referred to in the tables by the name of that county. 
suffer from drought or show a marked decrease in growth about the middle of the summer, particularly during the latter part of July and the first part of August. This is no doubt largely explained by the high temperatures that usually occus during this period, the mean temperature for the state for July and August being about $72.5^{\circ} \mathrm{F}$. In general, however, the climate of West Virginia is favorable to the growth of pastures.

\section{Soils}

As previously stated, the pasture areas studicd were selected so as to represent most of the important soils in West Virginia. Table 3 shows the acreage of the principal soils in each of the pasture areas studied. On the basis of their origin and general characteristies these soils can be classified into three main groups or provinces: (1) the Appalachian

\section{Table 2-Climatological data for the different areas}

\begin{tabular}{|c|c|c|c|c|c|c|c|}
\hline $\begin{array}{c}\text { Area } \\
\text { No. }\end{array}$ & $\begin{array}{c}\text { Counties } \\
\text { in } \\
\text { area }\end{array}$ & $\begin{array}{l}\text { Ave. } \\
\text { eleva- } \\
\text { tion of } \\
\text { farms } \\
\text { (feet) }\end{array}$ & $\begin{array}{l}\text { Eleva- } \\
\text { tion of } \\
\text { weath- } \\
\text { er sta- } \\
\text { tions } \\
\text { (feet) }\end{array}$ & $\begin{array}{l}\text { Frost } \\
\text { free } \\
\text { days }\end{array}$ & $\begin{array}{l}\text { Ave. } \\
\text { temp. } \\
\text { April } \\
\text { to } \\
\text { Sept. } \\
\left({ }^{\circ} \mathrm{F} .\right)\end{array}$ & $\begin{array}{l}\text { Ave. } \\
\text { annulal } \\
\text { rain- } \\
\text { fall } \\
\text { (in.) }\end{array}$ & $\begin{array}{l}\text { Ave. } \\
\text { rain. } \\
\text { fall } \\
\text { April } \\
\text { to } \\
\text { Sept. } \\
\text { (in.) }\end{array}$ \\
\hline 1 & Jackson & 775 & $58 t$ & $160-170$ & 67.3 & 41.3 & 20.9 \\
\hline 2 & Ritchie & 1035 & 1046 & $150-160$ & $65 . S$ & $4 \overline{5} .5$ & 24.5 \\
\hline 3 & Monongalia & 1280 & 1250 & $160-170$ & 66.0 & 42.7 & 23.4 \\
\hline 4 & Harrison & 1175 & 1026 & $150-160$ & $6+.5$ & 43.7 & 23.7 \\
\hline 5 & Marshall & 1155 & 645 & $155-170$ & 66.5 & $3 \$ .3$ & 21.4 \\
\hline 6 & $\begin{array}{l}\text { Pendleton } \\
\text { Hardy }\end{array}$ & 2010 & 1408 & $120-150$ & 63.9 & 29.7 & 17.8 \\
\hline 7 & $\begin{array}{l}\text { Pandolph } \\
\text { Pocahontas }\end{array}$ & 2565 & $225 \mathrm{~S}$ & $120-150$ & 61.6 & 52.2 & 27.7 \\
\hline 8 & $\begin{array}{l}\text { Greenbrier } \\
\text { Monroe }\end{array}$ & 2160 & 2400 & $140-160$ & 64.3 & 38.4 & 20.5 \\
\hline 9 & $\begin{array}{l}\text { Jefferson } \\
\text { Berkeley }\end{array}$ & 490 & 435 & $175-185$ & 66.8 & 37.1 & 21.0 \\
\hline
\end{tabular}

1Location of weather stations:

Area 1-Ravenswood

Area 2-Cairo, Buckhannon

Area 3-Morgantown

Area 4-Lost Creek
Area 5-Wheeling:

Area 6-Upper Tract, Brandywine

Area 7 -Elkins, Pickens, Marlinton

Area 8-Union, Lewisburg

Area 9-Martinsburg

All stations are over 25 yeal's old, except Ravenswood (12 years old) and Brandywine (19 vears old).

'Approximate number of days from last killing frost in spring to first killing frost in fall. 
Mountain and Platean, (2) the Limestone Valley and Upland, and (3) the River Flood Plain provinces.

\section{Soils of the Appalachian Mountain and Plalean}

The Dekalb* soils form the most extensive soil series found in the state and, as shown in colnmn 2 of Table 3 , are found in most of the areas studied. Derived from the disintegration of sandstones and shalcs they are inherently of relatively low fertility. The surface soil is yellowish to brown in color and as found in these areas is largely of siltloam to elay-loam texture. The subsoil consists of a brownish yellow silty clay loam to clay. The topography of Dekalb soils varies from gently rolling to very steep. Large acreages of these soils, especially in the southwestern part of the state, are too steep for pastures and are or should be in forests.

The Meigs soils are also found extensively in the state, especially in the western part. As shown in Table 3, the largest acreage of this soil is found in Area 2. The Meigs soils are derived from shales and sandstone and are similar to the Dekalb soils in topography and agrieultural value. Their color varies from light brown to reddish brown, and the texture is predominantly clay loam.

Two other important groups of soils of the Appalachian Mountain and Plateau Province are found fairly extensively in certain parts of the state although far less extensively than the Dekalb and Meigs soils. They are the Upshur and Westmoreland soils. These differ in origin from the Dekalb and Meigs in that they are derived partly from limy shales and impure limestones. For this reason and also because they are usually less rolling, they are considered to be better pasture soils than the Dekalb and Meigs soils. The Upshur soils vary considerably in the degree of limestone influence. In the Randolph-Pocahontas county area. which contains a large acreage of this soil at elevations of 3,000 to 4,000 feet, the soil has considerable limestone influence, having been formed from interbedded limy red shales, impure red or brown sandy limestone. and gray, nearly pure limestone. In the other area where it is found most extensively, the Jackson county area. the soil has been formed from limy red shales and gray shales and therefore has less limestone influence. Here the average elevation of the soil is about 800 feet. The surface of the Upshur soils are grayish red to Indian red in color and vary in texture from silt loam to clay. The subsoil is an Indian red silty elay loam to clay. In the Randolph-Pocahontas county area, where the soil is mostly a stony silt loam, very few of the pastures had ever been in cultivated crops, whereas in the Jackson county area, where the surface is mostly a clay loam. the soil was used for harvested crops before being turned into pasture.

The Westmoreland soil is represented chiefly in three of the areas studied, namely, in Harrison county (Area 4), in the Marshall county area (Area 5), and in scattered areas in Hardy and Pendleton counties

*In adjoining states soils similar to the Dekalb have recently been classified as Muskingum. 


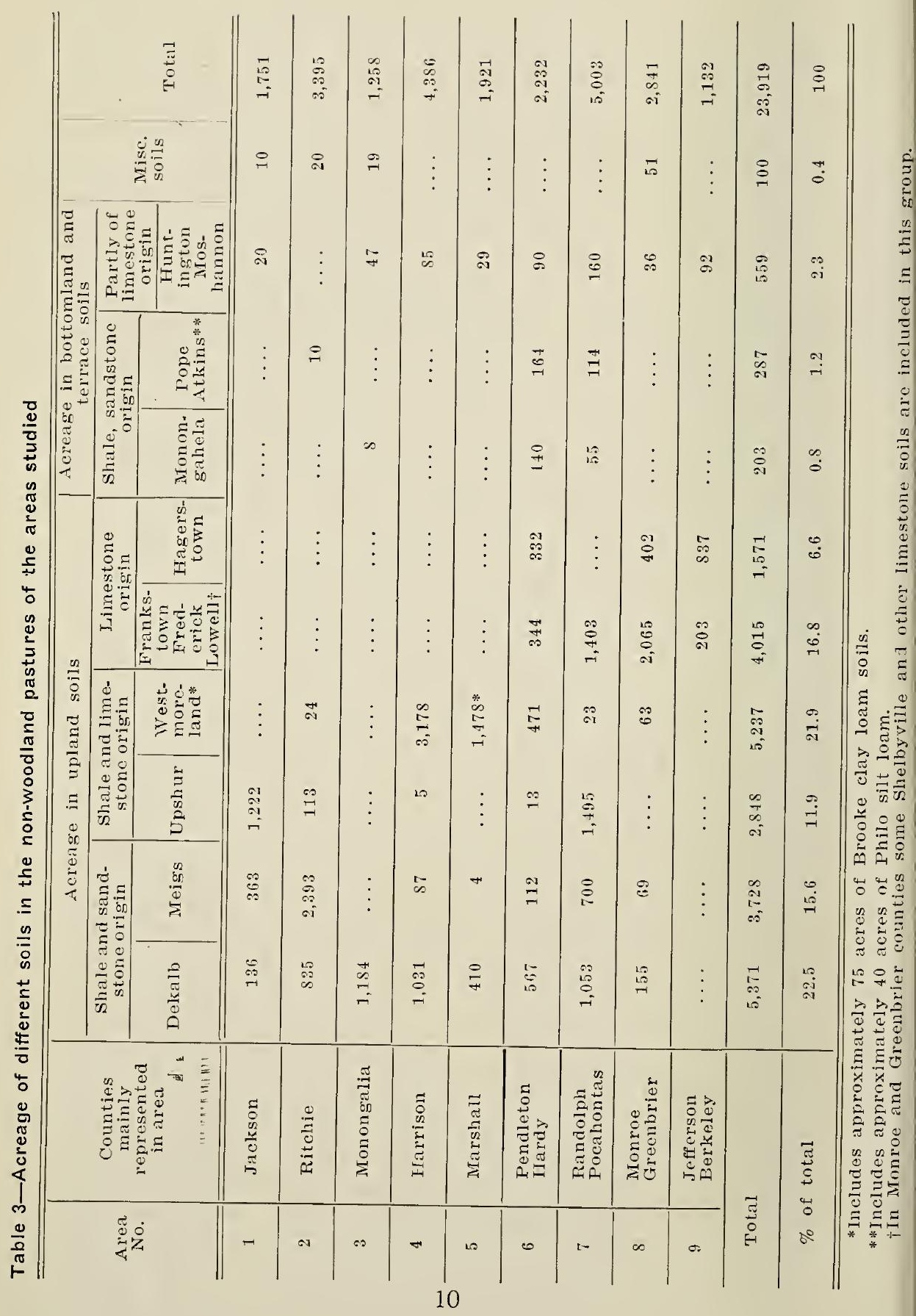


(Area 6). As shown in Table 3 , this soil represents $21.9 \%$ of the total pasture area studied. It is considered one of the best agricultural soils of the hilly, upland Appalachian Mountain and Plateau Province. The surface soil is generally a glayish brown or yellowish brown silt loam, and the subsoil is a yellowish brown silty clay loam.

\section{Limestone Valley and Upland Province}

The soils of limestone origin are found in the eastern portion of the state, principally in portions of the Eastern Panhandle and in counties along the Virginia line. Area 9 represents the limestone section of Jefferson and Berkeley counties, and Area 8 the limestone section of Nionroe and Greenbrier counties. The limestone soils in these areas are usualiy much less rolling than the soils of the Appalachian Mountain and Plateau Province and are considerably more fertile. The Frankstown, Frederick, and Lowell soils are grouped together in Table 3 because of their general similarity and because of the small acreage of Frederick and Lowell soils in the areas studied. The Frankstown soils are found largely in the Monioe-Greenbrier county area (Area 8). They are derived predominantly from gray siliceous limestone and to a slight extent from yellow ealeareous shales. The surface consists of a yellow to yellowish brown silt loam and the subsoil is a brownish yellow silty clay ioam to clay.

The Hagerstown soils are found mostly in the Jefferson-Berkeley county area (Area 9) and are derived from comparatively pure limestone. The surface soil consists of a reddish brown silt loam to clay loam

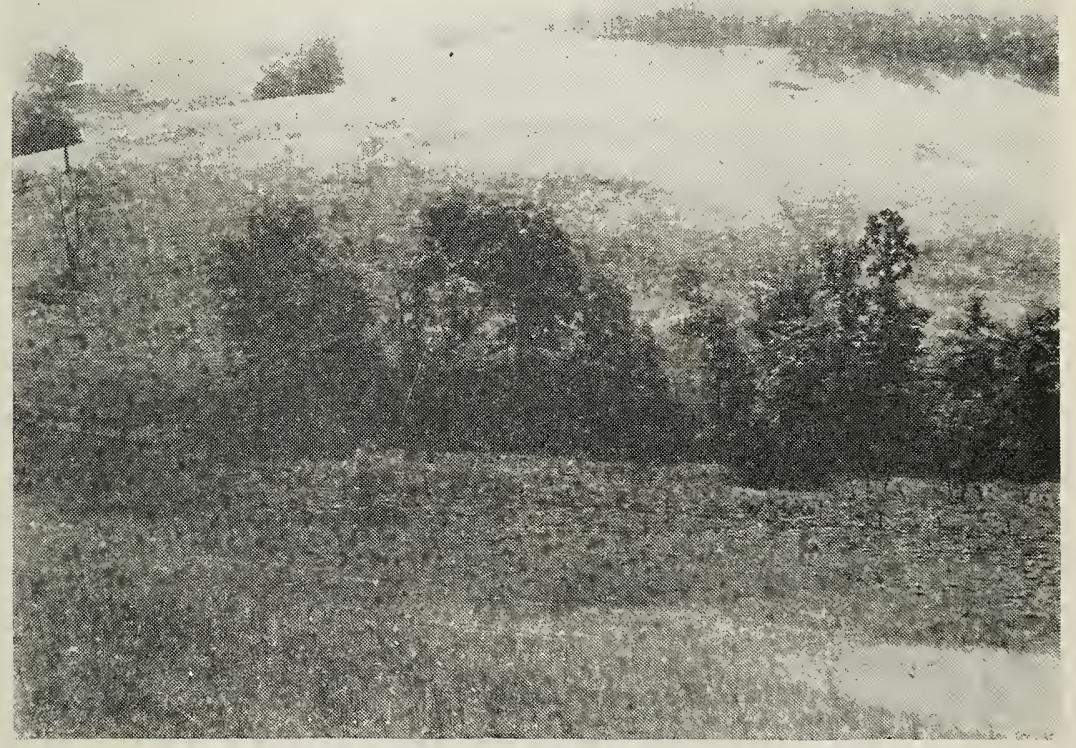

Typical topography, Westmoreland silt loam, Harrison County. 
and the subsoil is a rellowish brown to reddish brown silty elay loam. The topography is gently rolling, and outeropping ledges of limestone are numerons in some pastures.

\section{River Flood Plain Province}

The six upland soils deseribed make up more than $95 \%$ of the pasture area studied. The remainder consists of bottomland and terrace soils, as shown in Table 3. The most extensive areas of these soils are found in the Tygart Valley section of Randolph county (Area 7) and along the small streams in the Pendleton-Hardy eounty area. In the other areas the bottomland and terrace soils that are well drained are used mostly for harvested crops sinee they represent the most level areas on the farm. Where used for pasture they usually support the best pastures on the farm.

It is evident from these deseriptions and from the data in Table 3 that there are marked differenees among some of the areas because of differences in the origin and agrieultural value of the soils. Although several types of soil are found in every area, eaeh of the areas, except two, is representative mainly of one soil series. Thus Area 1 is representative of Upshur soil, Area 2 of Meigs, Area 3 of Dekalb, Areas 4 and 5 of Westmoreland, Area 8 of Frankstown, and Area 9 of Hagerstown. Areas 6 and 7 are representative not of any one series but rather of the narrow valleys and plateaus in the eastern mountainous part of the state.

Most of the soils of the different areas are of silt loam to clay loam texture, and thus have a water-holding eapaeity favorable for pasture production.*

\section{Pastures in Relation to Other Land in Farms}

Aecording to the eensus data, approximately $37.3 \%$ of the total land in farms in the state is in non-woodland pasture. The percentage value varies widely in the different sections, as shown in Figure 2. In IIonroe and Greenbrier counties, and in most of the counties in the northwest third of the state, over $40 \%$, and in some eases over $60 \%$, of the total farm land is in non-woodland pasture. Moreover, at least $80 \%$ of the aereage of most of these eounties is in farms (Fig A, Appendix). It is eviclent therefore that these counties eomprise two important livestock or grazing sections. Six of the nine areas selected for this study are situated in these seetions, Areas 1 and 5 inelusive in the western part of the state and Area 8 in Monroe and Greenbrier eounties.

In contrast to the seetions just referred to, the eounties in the southwestern part of the state have less than $25 \%$ of their total farm land in permanent pastures. Moreover, in some of these eounties only about 20 to $40 \%$ of the land is in farms. This means that less than $10 \%$ of the total area of this section is in permanent pastures (Fig. B, Appendix). It is, therefore, not an important pasture or livestoek area; and none

*A more complete description of all the soils can be found in the Soil Survey Report of the respective counties and in West Virginia Agricultural Experiment Station Bul. No. $281,1937$. 

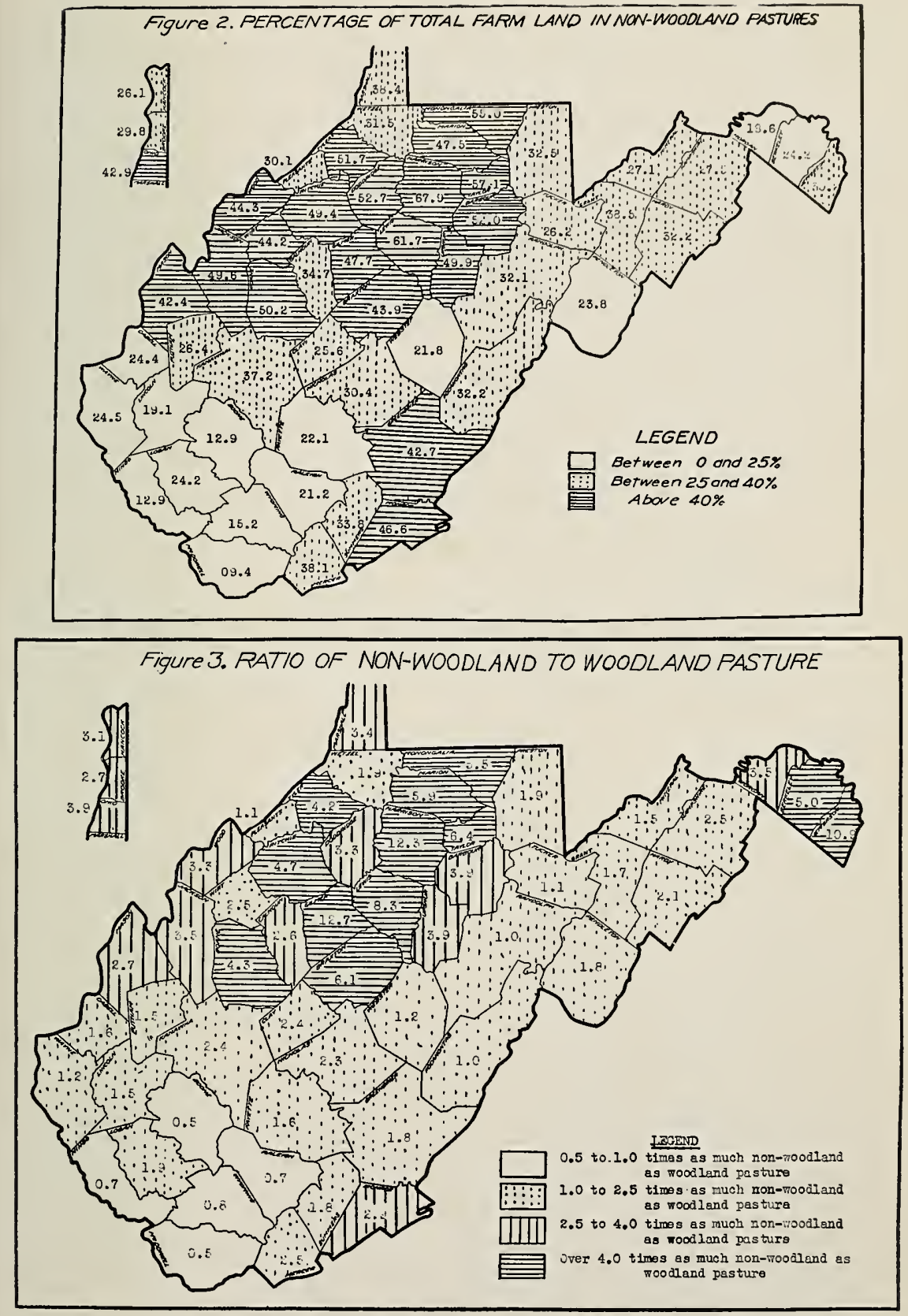
of the areas studied is in this section. Because of the steepness, the character of the soil, and the mineral wealth of this section, much of the land is best suited to forests and to industrial use.

In the castern third or so of the state approximately 25 to $35 \%$ of the total farm land is in non-woodland pasture (Fig. 2). This general section includes the principal mountain portion of the state as well as an area in Jefferson and Berkeley counties which lies in the Shenandoah Valley. Much of the steep mountain land still remains in forest or cutover land. In the small valleys and less rolling upland, however (Fig. 3 ), are found extensive acreages of open pasture which support a large number of livestock. Two of the pasture areas studied (Nos. 6 and 7) are in this section.

The limestone area in Jefferson and Berkeley counties, which has good soils of relatively level topography, constitutes one of the best

Table 4-Acreage of farm land in harvested crops, pasture, and woodland

\begin{tabular}{|c|c|c|c|c|c|c|}
\hline \multirow[b]{2}{*}{$\begin{array}{l}\text { Area } \\
\text { No. }\end{array}$} & \multirow[b]{2}{*}{$\begin{array}{l}\text { Counties } \\
\text { mainly } \\
\text { represented } \\
\text { in area }\end{array}$} & \multirow[b]{2}{*}{$\begin{array}{c}\text { Average } \\
\text { size of } \\
\text { furms } \\
\text { (acres) }\end{array}$} & \multicolumn{4}{|c|}{ Use of farin land } \\
\hline & & & $\begin{array}{l}\text { Har- } \\
\text { vested } \\
\text { crops } \\
\text { (acres) }\end{array}$ & $\begin{array}{c}\text { Per- } \\
\text { manent } \\
\text { pastures } \\
\text { (acres) }\end{array}$ & $\begin{array}{l}\text { Wood- } \\
\text { land } \\
\text { (not pas- } \\
\text { tured) } \\
\text { (acres) }\end{array}$ & $\begin{array}{l}\text { Farrn- } \\
\text { stead } \\
\text { and mis- } \\
\text { cellaneous } \\
\text { (acres) }\end{array}$ \\
\hline 1 & Jackson & 155 & 38.4 & 111.0 & 1.0 & 4.2 \\
\hline 2 & Ritchie & 173 & 29.4 & 139.6 & 1.8 & 2.4 \\
\hline 3 & Monongalia & 123 & 37.0 & $\$ 2.9$ & 0.1 & 3.3 \\
\hline 4 & Harrison & 159 & 30.1 & 125.1 & 1.5 & 2.2 \\
\hline 5 & Marshall & 160 & 55.3 & 92.9 & 6.5 & 5.2 \\
\hline 6 & $\begin{array}{l}\text { Pendleton } \\
\text { Hardy }\end{array}$ & 372 & 53.5 & 241.4 & 59.5 & 17.1 \\
\hline 7 & $\begin{array}{l}\text { Randolph } \\
\text { Pocahontas }\end{array}$ & 308 & 40.7 & $23 \$ .6$ & 24.9 & 3.6 \\
\hline 8 & $\begin{array}{l}\text { Greenbrier } \\
\text { Monroe }\end{array}$ & 191 & 45.8 & 140.0 & 0.8 & 4.5 \\
\hline 9 & $\begin{array}{l}\text { Jefferson } \\
\text { Berkeley }\end{array}$ & 200 & 126.0 & 53.3 & 7.6 & 12.7 \\
\hline \multicolumn{2}{|c|}{ Average (weighted) } & 203 & 49.0 & 137.7 & 10.6 & 5.6 \\
\hline \multicolumn{3}{|c|}{$\begin{array}{l}\text { Percentage of total farm } \\
\text { acreage (average) }\end{array}$} & 24.1 & 67.8 & 5.3 & 2.8 \\
\hline
\end{tabular}

IIncludes woodland and brush pasture. 
agricultural sections of the state. $\Lambda$ lthough the permanent pasture acreage in this area is only about $50 \%$ of the total land in harvested crops (Fig. 4), the pastures support an important dairy and livestock industry.

A summary of the acreage of pasture and harvested crops on the farms of the nine areas studice in this investigation is given in Table 4. The average size farm for all areas is 203 acres, and the range is from an average of 123 acres in the Monongalia county area to 372 acres in the Pendleton-Hardy county area. Of the total land in farms, an aver'age of 49 acres, or $24.1 \%$, is in harvested crops as compared with an average of 137.7 acres, or $67.8 \%$, in non-woodland and woodland pasture.

In Table 5, the permanent pasture is classificd into acres of open, brush, and woodland pastures. $\dagger$ Brush pastures constitute areas that were once open pasture but have been allowed to grow up in briers and bushes. In Area 1 the acreage in brush pastures averages about 20\%

Table 5-Acreages of open, brush, and woodland pasture per farm

\begin{tabular}{|c|c|c|c|c|c|c|}
\hline $\begin{array}{c}\text { Area } \\
\text { No. }\end{array}$ & $\begin{array}{l}\text { Counties } \\
\text { mainly } \\
\text { represented } \\
\text { in area }\end{array}$ & $\begin{array}{c}\text { Brush } \\
\text { pasture* } \\
\text { (acres) }\end{array}$ & $\begin{array}{l}\text { Wood- } \\
\text { land } \\
\text { pisture } \\
\text { (acres) }\end{array}$ & $\begin{array}{l}\text { Open } \\
\text { pisture } \\
\text { (acres) }\end{array}$ & $\begin{array}{l}\text { Percent- } \\
\text { age of } \\
\text { farm in } \\
\text { open } \\
\text { pasture }\end{array}$ & $\begin{array}{l}\text { Percent- } \\
\text { age of } \\
\text { farm in } \\
\text { crops }\end{array}$ \\
\hline 1 & Jackson & 16.4 & 17.9 & 76.4 & 49 & 25 \\
\hline 2 & Ritchic & 4.3 & 24.6 & 110.6 & 64 & 17 \\
\hline 3 & Monongalia & 2.5 & 10.9 & 69.6 & 57 & 30 \\
\hline 4 & Harrison & 2.7 & 7.7 & 114.7 & 72 & 19 \\
\hline 5 & Marshall & 2.1 & 18.0 & 72.8 & 45 & 35 \\
\hline 6 & $\begin{array}{l}\text { Pendleton } \\
\text { Hardy }\end{array}$ & 12.0 & 109.3 & 120.0 & 32 & 14 \\
\hline 7 & $\begin{array}{l}\text { Randolph } \\
\text { Pocahontas }\end{array}$ & 7.2 & 72.6 & 158.8 & 52 & 13 \\
\hline 8 & $\begin{array}{l}\text { Greenbrier } \\
\text { Monroe }\end{array}$ & 7.3 & 7.4 & 125.3 & 66 & 24 \\
\hline 9 & $\begin{array}{l}\text { Jefferson } \\
\text { Berkeley }\end{array}$ & 0.7 & 6.1 & 46.5 & 23 & 63 \\
\hline \multicolumn{2}{|c|}{ Average (weighted) } & 5.6 & 29.3 & 102.7 & 51 & 24 \\
\hline
\end{tabular}

* Pastures that contain considerable bushes and briers.

†Open pastures refer to permanent pastures which do not contain enough trees and bushes to decrease the value of the pasture. 
of that in oper pasture, but in Area 9 only about 2\%. Brush pastures average 5.6 acres per farm and woodland pasture, 29.3 acres per farm. As might be expected, the ratio of woodland to open pastures varies considcrably in the different areas. Thus in the Harrison county area there is about 15 times as much open as woodland pasture, whereas in the Pendleton-Haldy county area there is about as high an acreage of woodland as of open pasture. A more gencral picture of the ratio of nonwoodland to woodland pasture by counties, as obtained from the census data, is given in Figure 3.

In the last two columns of Table 5 is shown the percentage of the farms in open pastures and in harvested crops. In general the acreage in open pasture is from two to four timcs the acreage in harvested crops. This ratio is determined largely by the amount of land available for harvested crops. Thus in the .Jefferson-Berkeley county area (No. 9). where the soils are level to gently rolling, there is less than half as much open pasture as of harrested crop land; whereas in Areas 2, 4, and 7, which as shall be seen later (Table 14) have much steep land, there is nearly four times as much open pasture as crop land. As an average for all areas studied, 51\% of the farm acreage is in open pasture and $24 \%$ in harvested crops. A general picture of the ratio of non-woodland pasture to land in harvested crops by counties, based on census data. is shown in Figure 4.

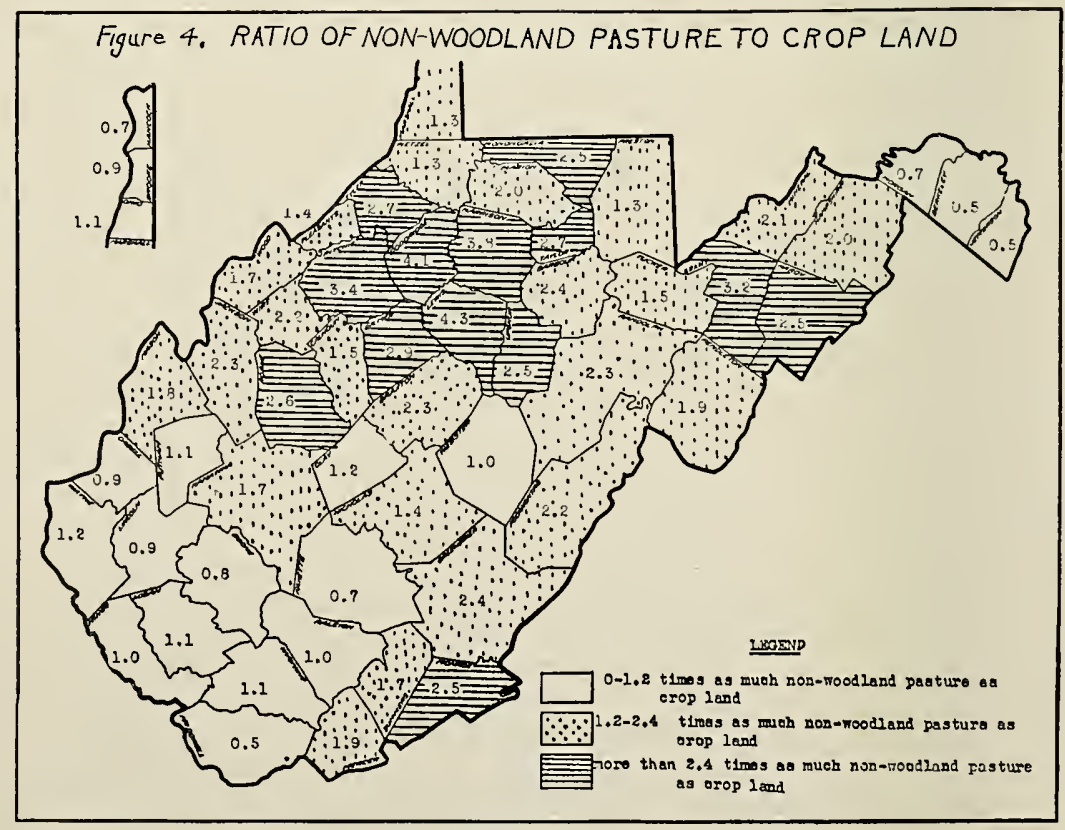




\section{Kind of Animals Pastured}

Each of the nine areas studied was elassified according to the kind of animals pastured. In this elassification, shown in Table 6 , beef eattle, sheep, horses, and mules are grouped as "livestock", whereas dairy cattle are classified separately. The justification for this distinction is; based on the more extensive methods of beef cattle and sheep production contrasted with the more intensive methods of dairy farming. In orde: to be able adequately to compare one area with another the data are reported in terms of "animal units." In ealeulating animal units, one horse, mule, bull, steer, or cow, two colts or yearling cattle, four calves, seven yearling or older shcep, and fourteen lambs were considered each us an animal unit.

In general, those areas in which 50 pereent or more of the animal units are livestock are classed as livestock areas; those in which 30 percent or more of the animal units are dairy, are elassed as dairy ; and those with a relatively large amount of land in harvested crops (Table 4) are classed as general. As previously mentioned, the farms studied in Area 3 represent the dairy farms of the area. Considerable numbers of sheep and beef cattle are also produced in this area. Therefore the ratio

\section{Table 6-Type of animals pastured in areas studied}

\begin{tabular}{|c|c|c|c|c|c|c|}
\hline \multirow{2}{*}{$\begin{array}{l}\text { Area } \\
\text { No. }\end{array}$} & \multirow{2}{*}{$\begin{array}{l}\text { Counties } \\
\text { main!y } \\
\text { represented } \\
\text { in area }\end{array}$} & \multirow[b]{2}{*}{ Type of farm } & \multicolumn{4}{|c|}{$\begin{array}{l}\text { Animals pastured } \\
\text { ( } \% \text { of total animal units) }\end{array}$} \\
\hline & & & $\begin{array}{l}\text { Beef } \\
\text { cattle }\end{array}$ & $\begin{array}{l}\text { Dairy } \\
\text { cattle }\end{array}$ & Sheep & $\begin{array}{l}\text { IJorses } \\
\text { and } \\
\text { mules }\end{array}$ \\
\hline 1 & Jackson & Livestock-general & 63.5 & 15.8 & 8.8 & 11.9 \\
\hline 2 & Ritchie & Livestock & 51.9 & 19.5 & 20.3 & $\$ .3$ \\
\hline 3 & Monongalia & Dairy-general & 8.9 & 84.6 & 0 & 6.5 \\
\hline 4 & Marrison & Livestock--dairy & 45.1 & 34.2 & 10.0 & 10.7 \\
\hline 5 & Marshall & Dairy-general & 5.7 & 62.7 & 24.3 & 7.3 \\
\hline 6 & $\begin{array}{l}\text { Pendleton } \\
\text { Hardy }\end{array}$ & Livestock & 71.6 & 3.0 & 19.3 & 6.1 \\
\hline 7 & $\begin{array}{l}\text { Randolph } \\
\text { P'ocahontas }\end{array}$ & Livestock & 66.3 & 9.0 & 19.4 & 5.3 \\
\hline 8 & $\begin{array}{l}\text { Monroe } \\
\text { Greenbrier }\end{array}$ & Livestock-general & 64.5 & 15.9 & 12.3 & 7.3 \\
\hline 9 & $\begin{array}{l}\text { Jefferson } \\
\text { Berkeley }\end{array}$ & General-dairy & 11.8 & 53.7 & 15.2 & 19.3 \\
\hline Av & ge (weighte & & 45.6 & 30.4 & 15.3 & 8.7 \\
\hline
\end{tabular}


of dairy eattle to other cattle in Area 3 , as given in Table 6 , is considerably ligher than is actually true of this entire area.

Six of the areas, $1,2,4,6,7$, and 8 , are classed as livestock areas, and each of these areas is predominantly a becf cattle section. Five of these areas aiso produce large numbers of sheep, most of which are medium wool or mutton type. Areas 5 and 9 also produce considerable number's of sheep, but relatively few beef cattle. The large sheep population in Area 5 is principally of fine-wool type, this district bcing near the center of the tri-state fine-wool territory. Sheep production in Area 9 consists principally of early lamb production for the spring market. This area is the most favorably situated of any section of the state with respect to markets, being near Washington and Baltimore. These cities use large numbers of early spring lambs and pay a premium for them. Since this area also produces milk for these same markets it has a large proportion of dairy cattle. The other two dairy areas, 4 and 5 , include large urban populations for which milk is produced locally.

The number of horses is in a general way proportional to the percentage of land cultivated. Area 9 has the highest percentage of land in cultivation and the largest proportion of horses, whereas Areas 6 and 7 have the lowest percentage of land in cultivation and the fewest horse units.

\section{The Carrying Capacity ${ }_{2}$ Pastures}

The final measure of the value of pasture is the number of animal units that the pasture will support. In order to calculate the carrying capacity of the non-woodland pasture it was necessary first to determine the amount of grazing afforded by woodland pasture and meadow aftermath, and the amount of supplemental feed supplied during the pasture season. The carrying capacity of woodland pastures was difficult to evaluate and varied widely. Based on the best information available, an average of 30 acres of woodland pasture was estimated to be necessary to pasture one animal unit. Some woodland pastures have a somewhat higher carrying capacity, whereas others that are more thickly wooded have a considerably lower carrying capacity.

The importance of the different kinds of pasture is shown in Table 7. By far the largest proportion of the feed was supplied by nonwoodland pasture. In Area 6 an appreciable part of the pasturage, or approximately $13.5 \%$, was obtained from extensive areas of unfenced mountain woodland. Meadow aftermath supplied a considerable share of the feed in Areas 7 and 9. In Area 7 meadows were situated principally on bottom lands and were used for pasture in the fall when the animals were first brought in from the mountain pasture. In Jefferson and Berkeley counties the large percentage of pasture on meadow aftermath reflected the relatively large proportion of cultivated land.

The barn feed, expressed as a pereentage of the feed supplied by pasture, appears in the right-hand column of Table 7 . The dairy sec- 
tions, Areas 3, 4, and 5, were highest in the use of supplemental feed. Area 9, also a dairy section, depended largely on meadow aftermath instead of grain or hay.

The earrying eapacities of the arcas surveyed are shown in Table 8. These values were obtained by dividing the acreage of non-woodland pasture by the total number of animal units which were supported by the non-woodland pastures. It will be noted that the pastures of the different areas studied differed very much in their carrying eapacities. Areas 2 and 4 required an average of five or more acres to pasture one animal unit whereas Area 9 required an average of $2^{1 / 2}$ acres, or only onehalf as much. The other areas range between these two extremes. There is, of course, a wide variation in the carrying capacity of different pastures within an area.

In the last column of Table 8 are given values for carrying eapacity calculated from the census data. These values cannot be compared directly with the survey values, since they represent the entire counties,

Table 7-Feed furnished by different types of pasture and by supplemental barn feeding

\begin{tabular}{|c|c|c|c|c|c|c|}
\hline \multirow{2}{*}{$\begin{array}{l}\text { Area } \\
\text { No. }\end{array}$} & \multirow{2}{*}{$\begin{array}{l}\text { Counties } \\
\text { mainly } \\
\text { representea } \\
\text { in area }\end{array}$} & \multicolumn{3}{|c|}{$\begin{array}{l}\text { Percentage of herbage supplied } \\
\text { by different kinds of pasture }\end{array}$} & \multirow{2}{*}{$\begin{array}{l}\text { Meadow } \\
\text { after- } \\
\text { math } \\
\text { grazed } \\
\text { (As\% of } \\
\text { area in } \\
\text { open } \\
\text { pasture) }\end{array}$} & \multirow{2}{*}{$\begin{array}{l}\text { Barn } \\
\text { feed } \\
\text { (As\% of } \\
\text { feed sup- } \\
\text { plied by } \\
\text { pasture) }\end{array}$} \\
\hline & & $\begin{array}{l}\text { Non. } \\
\text { wondland } \\
\text { pasture }\end{array}$ & $\begin{array}{l}\text { Wood- } \\
\text { land } \\
\text { pasture }\end{array}$ & $\begin{array}{l}\text { Meadow } \\
\text { after- } \\
\text { math* }\end{array}$ & & \\
\hline 1 & Jackson & 95.0 & 3.0 & 2.0 & 10.2 & 0.9 \\
\hline 2 & Ritchie & 94.3 & 3.5 & 2.2 & 3.3 & 0.3 \\
\hline 3 & Monongalia & 92.2 & 3.7 & 4.1 & 15.6 & 23.4 \\
\hline 4 & Harrison & 96.2 & $0 . S$ & 3.0 & 4.5 & 6.8 \\
\hline 5 & Marsha11 & 96.2 & 1.8 & 2.0 & 4.8 & 6.1 \\
\hline 6 & $\begin{array}{l}\text { Pendleton } \\
\text { IAardy }\end{array}$ & 82.6 & 13.9 & 3.5 & 11.6 & 0.3 \\
\hline 7 & $\begin{array}{l}\text { Randolph } \\
\text { Pocahontas }\end{array}$ & 88.3 & 4.6 & 7.1 & 17.3 & 0.2 \\
\hline 8 & $\begin{array}{l}\text { Monroe } \\
\text { Greenbrier }\end{array}$ & 95.7 & 0.9 & 3.4 & 8.5 & 4.1 \\
\hline 9 & $\begin{array}{l}\text { Jefferson } \\
\text { Berkeley }\end{array}$ & 68.6 & 0.7 & 30.7 & 77.2 & 1.8 \\
\hline \multicolumn{2}{|c|}{ Average (weighted) } & 90.0 & 3.4 & 6.6 & 12.5 & 4.0 \\
\hline
\end{tabular}

* Includes also a very small acreage of special pasture crops. 
while the survey values are for only parts of the counties listed. Moreover, they should be considered approximate, since no corrections could be made for feed furnished by meadow aftermath, temporary pastures, and barn feeding. It is interesting to note, however, that in four of the areas, Nos. 4, 5, 6, and 9, the survey and census values are similar. Since the farms ehosen in Area 3 were dairy farms and represented better conditions than the average, and since the farms selected in Monroe and Greenbricr counties were from only the limestone sections of these counties, it is readily evident why the carrying capacity of these areas as obtained by the survey is higher than that calculated from the census data. The average carrying eapacity of the total area surveyed was 4.2 acres per animal unit. Since as previously described, these areas represent a large proportion of the better pasture soils than is found in the state as a whole, it is estimated from these data and from the census data that the average carrying eapacity for all non-woodland pastures of the state is approximately 5 acres per animal unit.

\section{Table 8-Comparison of carrying capacity of non-woodland pastures as shown by survey and by census data}

\begin{tabular}{|c|c|c|c|c|c|}
\hline \multirow{2}{*}{$\begin{array}{l}\text { Area } \\
\text { No. }\end{array}$} & \multirow{2}{*}{$\begin{array}{l}\text { Counties } \\
\text { mainly } \\
\text { represented } \\
\text { in area }\end{array}$} & \multirow{2}{*}{$\begin{array}{l}\text { Animal } \\
\text { units sup- } \\
\text { plied by } \\
\text { pasture }\end{array}$} & \multirow{2}{*}{$\begin{array}{l}\text { Acres } \\
\text { of } \\
\text { pasture }\end{array}$} & \multicolumn{2}{|c|}{$\begin{array}{c}\text { Acres of pasture per } \\
\text { allimal unit }\end{array}$} \\
\hline & & & & Survey & Census* \\
\hline 1 & Jackson & 404 & 1772 & 4.4 & 5.7 \\
\hline 2 & Ritchie & 615 & 3285 & 5.3 & 6.7 \\
\hline 3 & Monongalia & 423 & 1263 & 3.4 & 5.2 \\
\hline 4 & Harrison & $\$ 84$ & 4111 & 5.0 & 5.2 \\
\hline 5 & Marshall & 609 & 1921 & 3.1 & 3.2 \\
\hline 6 & $\begin{array}{l}\text { Pendleton } \\
\text { Hardy }\end{array}$ & 474 & 2240 & 4.7 & 4.6 \\
\hline 7 & $\begin{array}{l}\text { Randolph } \\
\text { Pocahontas }\end{array}$ & 1235 & 4993 & 4.0 & 4.7 \\
\hline 8 & $\begin{array}{l}\text { Monroe } \\
\text { Greenbrier }\end{array}$ & 773 & $2 \$ 49$ & $3 . \bar{i}$ & 5.1 \\
\hline 9 & $\begin{array}{l}\text { Jefferson } \\
\text { Berkeley }\end{array}$ & 454 & 1132 & 2.5 & 2.8 \\
\hline AlI & areas & 5870 & 23,866 & $\begin{array}{c}4.2 \\
\text { (weighted } \\
\text { average) }\end{array}$ & $\begin{array}{c}5.2 \\
\text { (average } \\
\text { for state) }\end{array}$ \\
\hline
\end{tabular}

* Census data are for entire counties, whereas the survey data are for parts of the counties listed. In calculating, the carrying capacity of the woodland pasture was taken as $30 \mathrm{~A}$. per animal unit. 


\section{Type of Vegetation in Open Pastures}

It has long been recognized that the value or carrying capacity of a permanent pasture is materially affected by the kinds of grasses, legumes, and weeds making up the pasture vegetation and by the density of the turf. The better types of pasture plants prodnce not only a denser sod and a greater yield per acre than do poor native grasses and weeds, but also a herbage of higher quality or nutritive value. The two most irr:portant desirable species in West Virginia pastures are Kentucky bluegrass and white clover. It is a well-established fact that these plants are found in permanent pastures in West Virginia wherever the fertility of the soil has been well maintained. Moreover, experimental work on poor pastures containing only small amounts of bluegrass and white clover has proved that the application of lime and superphosphate to such pastures will generally bring back a good sod of bluegrass and white clover. Other desirable species often found in small amounts in pastures are timothy, orchard grass, red top and other bent grasses, Canada bluegrass, red clover, lespedeza, and hop clover.

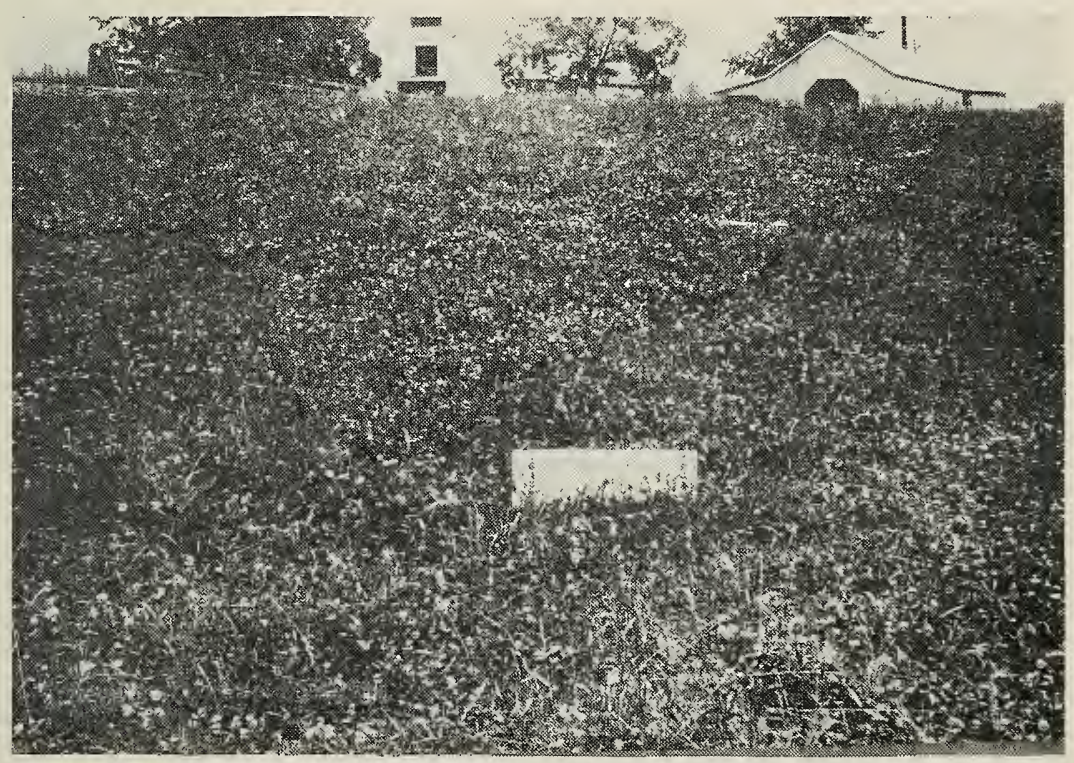

A good white clover pasture, Hagerstown silt loam, Jefferson County. 


\section{Desirable Species Present in Pastures Studied}

Within each of the nine areas studied there was a wide difference in the pereentage of the various desirable plant speeies present. Even in the poorest of the nine areas there were found on many farms a few acres of pasture near the barn where a high percentage of desirable plants was present. On the other hand many pastures were found to have a thin sod eomposed mostly of poor native grasses and weeds. A summary of the average percentages of desirable pasture grasses and legumes found in the pastures of the different areas is given in Table 9. One of the most significant results is the low percentage of Kentucky bluegrass

Table 9-Percentage distribution of desirable pasture grasses and legumes in different areas

\begin{tabular}{|c|c|c|c|c|c|c|c|c|c|c|}
\hline \multirow[b]{2}{*}{$\begin{array}{l}\text { Area } \\
\text { No. }\end{array}$} & \multirow[b]{2}{*}{$\begin{array}{l}\text { Counties } \\
\text { mainly } \\
\text { represented } \\
\text { in area }\end{array}$} & \multicolumn{9}{|c|}{$\begin{array}{c}\text { Average percentages (on basis of } 100 \text { for perfect } \\
\text { stand or dense sod) } 1\end{array}$} \\
\hline & & 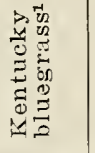 & 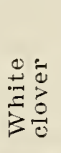 & $\begin{array}{l}0 \\
0 \\
0 \\
0 \\
0 \\
0\end{array}$ & 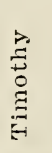 & 邑完 & 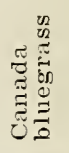 & 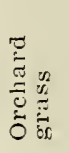 & 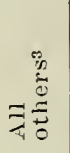 & 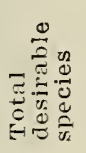 \\
\hline 1 & Jackson & 2.9 & 1.3 & 1.9 & 0.2 & 0.7 & 0.2 & 0.1 & 6.2 & 13.5 \\
\hline 2 & Ritchie & 3.8 & 1.2 & 0.4 & 0.4 & 1.9 & 0.2 & 0.2 & 2.5 & 10.6 \\
\hline 3 & Monongalia & 10.4 & 1.2 & 6.1 & 1.6 & 0 & 0 & 2.6 & 0 & 21.9 \\
\hline 4 & Harrison & 11.6 & 2.4 & 2.2 & 2.1 & 0.8 & 0.6 & 0.4 & 0.1 & 20.2 \\
\hline 5 & Marshall & 23.3 & 3.8 & 6.4 & 2.9 & 0 & 0.8 & 0.3 & 0.3 & 37.8 \\
\hline 6 & $\begin{array}{l}\text { Pendleton } \\
\text { Mardy }\end{array}$ & 12.9 & 2.9 & 2.7 & 1.6 & 0.5 & 2.5 & 0 & 0.0 & 23.9 \\
\hline 7 & $\begin{array}{l}\text { Randolph } \\
\text { Pocahontas }\end{array}$ & 8.2 & 3.6 & 5.9 & 4.3 & 0.2 & 0.3 & 1.1 & 1.3 & 24.9 \\
\hline 8 & $\begin{array}{l}\text { Greenbrier } \\
\text { Monrne }\end{array}$ & 13.2 & 4.3 & 2.4 & 4.4 & 5.6 & 1.1 & 0.2 & 1.3 & 32.5 \\
\hline 9 & $\begin{array}{l}\text { Jefferson } \\
\text { Berkeley }\end{array}$ & 30.8 & 6.0 & 2.1 & 1.3 & 2.8 & 2.5 & 1.1 & 0.3 & 46.9 \\
\hline Ave & ge (weighted) & 11.6 & 3.0 & 3.4 & 2.5 & 1.4 & 0.8 & 0.6 & 1.3 & 24.4 \\
\hline
\end{tabular}

\section{'Scientific names:}

Kentucky bluegrass-(Poa pratensis)

White clover-(Trifolium repens)

Red top-(Agrostis alba)
Hop clover-(Trifolium spp.)

Canada bluegrass-(Poa compressa)

Orchard grass-(Dictylis glomerata)

Timothy-(Phleum pratense)

2Includes other bent grasses (Agrostis spp.)

aPrincipal species in this group are red clover and meadow feseue in most of the areas, but Common lespedeza predominates in Areas 1 and 2. 
found in most of the areas (column 3). Area 2, which as previously mentioned represents a Jarge area of non-limestone soils in the western part of the state, has on an average only $3.8 \%$ bluegrass. Five of the areas average between 8 and $20 \%$ and only two areas have more than a $20 \%$ stand of Kentucky bluegrass; the weighted average for all the pastures studied is $\mathbf{1 1 . 6 \%}$.

White clover, the other most important species, is also very low in most areas. The percentage values range from about $1.2 \%$ in the nonlimestone areas of the western part of the state (Areas 1, 2, and 3) to $6.0 \%$ in the limestone area of Jefferson and Berkelcy counties (Area 9;. The other desirable species in the order of their abundance are redtop, timothy, hop elover, Canada bluegrass, and orehard grass. Hop clover has a rather short growing period, but it produces considerable growth in certain years. Being a legume, it is a valuable species for the nitrogen it supplies to the grasses growing in association. In the Jackson county area (No. 1) and in the Ritchie county area (No. 2) a considerable amount of common lespecieza was found in many pastures. This plant is a very valuable species in pasture regetation because it is a legume and because it makes most of its growth during midsummer. None or very little was found in the other sections except in the Greenbrier-Monroe county area, thus indicating that this species is probably best adapted to the southern part of the state.

The average percentages of total desirable species are shown in the last column of Table 9. In Areas 1 and 2 less than 15\% of the stand is made up of desirable species, and in only three areas do the pastures average more than $30 \%$ desirable species. The average for all pastures is only $24.4 \%$.

\section{Undesirable Pasture Species and Bare Space}

Of the poor native grasses growing in West Virginia pastures, poverty grass (Danthonia spicata) is found in greatest abundance. This plant is late in starting growth in the spring; and, although it furnishes fair pasture when in the young vegetative stage of growth, it is a poor pasture plant because it produces low yields and herbage of relatively low quality. As shown in Table 10, the average percentage of poverty grass in all the areas studied is $\mathbf{1 8 . 2 \%}$. In Area 7 (Randolph and Pocahontas counties) it averages over $30 \%$, whereas in Area 9 (Jefferson and Berkeley counties), which has previously been shown to be high in desirable pasture plants, it averages only $0.5 \%$ Broomsedge is the second most abundant native grass found in the state and like poverty grass produces herbage of low quality. Although generally distributed, it is found in greatest abundance in the southern areas of the state, where it apparently displaces poverty grass to some extent. As shown in Table 10 , the greatest abundance of broomsedge is found in the Jackson county area, where it makes up $19.3 \%$ of a stand. The other three areas where broomsedge is found in greatest abundance are Area 2 (Ritchie county), Area 4 (Harrison county), and Area 8 (Monroe and Greenbrier counties). 
The percentage of weeds in the various areas is relatively high, avel'aging $20.5 \%$ for all the area studied. The most abundant weeds in most of the areas are cinquefoil, buckhorn plantain, ox-cye claisy, yarrow, wild carrot, field sorrel, and ragweed. Although some of these weeds are eaten when in the young vegetative stage of growth, most of then soon get coalse and remain meaten. The total percentage of weeds and of poor or undesirable pasture species in the different areas (Table 10) ranges from $29.1 \%$ in the Jefferson-Berkeley county area to around $60 \%$ in sereral of the areas, and the weighted average for all pastures studied is $51 \%$.

The area not taken up by plants is referred to as bare space. and the values obtained for the different areas are shown in the last column of the table (Table 10). As an average, $24.6 \%$ of the ground in the pastures studied was not covered with regetation. This does not mean

Table 10-Percentage distribution of poor native grasses, weeds, and bare space in the pastures

\begin{tabular}{|c|c|c|c|c|c|c|c|c|}
\hline \multirow[b]{2}{*}{$\begin{array}{l}\text { Area } \\
\text { No. }\end{array}$} & \multirow[b]{2}{*}{$\begin{array}{l}\text { Counties } \\
\text { mainly } \\
\text { represented } \\
\text { in area }\end{array}$} & \multicolumn{7}{|c|}{$\begin{array}{c}\text { Average percentage (on basis of } 100 \text { for perfect } \\
\text { stand or dense sod) }\end{array}$} \\
\hline & & $\begin{array}{l}\text { Pov- } \\
\text { erty } \\
\text { grass } \\
\text { (Dan- } \\
\text { thonia } \\
\text { spicata) }\end{array}$ & $\begin{array}{c}\text { Bronm- } \\
\text { sedge } \\
\text { (Andro- } \\
\text { pogon } \\
\text { vir- } \\
\text { ginicus) }\end{array}$ & $\begin{array}{l}\text { Sedges } \\
\text { and } \\
\text { Juncus }\end{array}$ & $\begin{array}{c}\text { MTis- } \\
\text { cella- } \\
\text { neous } \\
\text { spe- } \\
\text { cies }^{1}\end{array}$ & Weeds & $\begin{array}{l}\text { Total } \\
\text { unde- } \\
\text { sir- } \\
\text { able } \\
\text { plants }\end{array}$ & $\begin{array}{l}\text { Bare } \\
\text { space }\end{array}$ \\
\hline 1 & Jackson & 11.6 & 19.3 & 0.2 & $b .1$ & 21.9 & 59.1 & 27.4 \\
\hline 2 & Ritchie & 22.5 & 9.4 & 2.8 & 1.7 & 23.9 & 60.3 & 29.1 \\
\hline 3 & Monongalia & 19.2 & 1.1 & 1.3 & trace & 24.2 & $45: 8$ & 32.1 \\
\hline 4 & Harrison & 19.6 & 9.1 & 5.5 & 2.8 & $1 S . S$ & 55.8 & 24.0 \\
\hline 5 & Marshall & s.: & 0.7 & 4.0 & 4.1 & 15.3 & 32.4 & 29.8 \\
\hline 6 & $\begin{array}{l}\text { Pendleton } \\
\text { Hardy }\end{array}$ & 14.2 & 2.5 & 4.3 & 5.3 & 18.1 & 44.4 & 31.7 \\
\hline 7 & $\begin{array}{l}\text { Randolph } \\
\text { Pocahontas }\end{array}$ & 30.1 & 1.6 & 0.4 & 6.7 & 20.7 & $\div 9.5$ & 15.6 \\
\hline 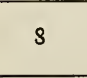 & $\begin{array}{l}\text { Greenbrier } \\
\text { Monroe }\end{array}$ & 11.5 & 4.3 & 1.8 & 4.3 & 21.7 & 43.6 & 23.9 \\
\hline 9 & $\begin{array}{l}\text { Jefferson } \\
\text { Berkeley }\end{array}$ & 0.5 & 0 & 0.4 & 5.8 & 22.4 & 29.1 & 24.0 \\
\hline Ave & ge (weighted) & $1 S .2$ & 5.4 & 2.5 & 4.4 & 20.5 & 51.0 & 24.6 \\
\hline
\end{tabular}

1Miscellaneous species, particularly in areas containing highest percentages, were: foxtail, cheat, Paspalum, nimble will, three-awn grass, and crab grass.

'Predominant weeds, in approximate order of prevalence, were: cinquefoil, bucklorn plantain, ox-eye daisy, yarrow, wild carrot, field sorrel, and ragweed. 
that there were large areas bare of vegetation making up $24.6 \%$ of the pasture area, but rather that the vegetation present failed to this extent to form a dense or perfect stand.*

It is thus evident that many of the pastures of the state not only lack the type of vegetation essential to good pastures, but that the pasture cover or sod is much too thin. As an average for all pasture areas studied, only $24.4 \%$ or approximately one-fourth of the ground was taken up by valuable or desirable pasture grasses and legumes, about onehalf $(51.0 \%)$ by poor native grasses and weeds, and the remaining onefourth $(24.6 \%)$ by bare space.

In considering these data it should, of course, be recognized that the proportion of different species and the amount of bare space will vary at different times during the season. Thus very early in the spring or during dry periods of midsummer the sod is thinner than at periods of more optimum growth. As previonsly shown (Table 1), most of the botanical analyses reported in this investigation were made during June and the early part of July when the vegetation was making active growth. The rainfall was above normal in all areas during May and June except in Area 9 during Mlay and Area 6 during June. Consequently, with the possible exception of Area 6 , the percentage of desirable species in the pastures at the time the estimates were made was probably as high if not slightly higher than at other times during the season.

The question may also be raised as to what effect the relatively dry seasons experienced since 1930 have had on the type of vegetation in the pastures. Because of unfavorable seasons, total pasture production was low in most sections of the state during 1930, 1932, and 1934. There probably were also some decreases in the percentage of Kentucky bluegrass and other desirable species during these years, especially where the plants were weak. Where the soil conditions were satisfactory for bluegrass and other desirable species. however, the favorable moisture conditions in the spring and early summer of 1935 should have caused a satisfactory restoration of these desirable species.

\section{Pasture Management}

Several factors which may be called management practices are important in determining the proportion of desirable and undesirable plants in pastures and the amount of plant growth.

*A dense sod of Kentucky bluegrass and white clover as found in lawns and good pastures was considered a perfect stand and used as the standard of comparison. 
The management practices include:

1. Time of turning livestock on pasture in spring

2. Time of removing animals from pasture in fall

3 . Leaving animals on pasture all winter

4. Closeness of grazing

5. Mowing weeds and briers

6. Frequency of reestablishing pastures

7. Soil treatment

The data obtained in this study show that many farmers begin grazing in the spring at least two weeks before the pastures are ready. The time when animals are turned into pasture in the spring has considerable influence on the amount of feed that the pasture will supply that season, and it will eventually affect the kind of plants growing in the pasture. If pastures are grazed while the ground is still soft, the soil may become puddled, and many plants will be destroyed. In the early spring not only is the grass too short to provide mueh nourishment for the animal, but the early grazing will decrease the produetivity of the pasture. Horeover, the desirable plants are weakened by the early grazing and are more likely to be crowded out by undesirable plants. In general, the vegetation should average 3 or 4 inches in height before grazing is started. The average date will ordinarily be during the last week of April or the first week of May except on very poor pastures or in the mountainous sections of the state.

In most areas the cattle are removed from the pastures between early Oetober and the middle of November, depending mainly on the altitude. Some farmers reported leaving their cattle and sheep on pasture until early December. Experimental work at this Station and praetieal experience have shown that cattle left on pasture after about the first of November lose weight because of insuffieient feed supply. In this connection a number of fármer's questioned in this survey stated that they left cattle or sheep on pasture all winter. This is injurious to both the animals and the pasture. The majority of these animals are young, growing ealves or lambs, or breeding females. Both these elasses of livestock should reeeive liberal amounts of feed rich in protein and minerals. Heavy losses usually accompany the praetice of keeping livestock on pasture during the entire winter without supplemental feed.

Late fall and winter grazing is injurious to pastures for reasons similar to those applying to early spring grazing. The soil is usually quite soft during late fall and winter, permitting damage from tramping. If the pasture is elosely grazed in the fall not only are the plants weakened but there is little opportunity for the development of a mulch which protects the plant roots and helps prevent soil washing.

A summary of the intensity of grazing in the different areas at the time the survey was made (See Table 1) is given in Table 11. It will be noted that a large proportion of most of the areas falls in the "medium grazing" class, the average percentage for all areas in this class being $58.6 \%$. In several of the areas, however, a considerable percentage of 
the pasture area is lightly grazed (Areas 6, 7, 8, and 9). These areas oceur in the castern part of the state and, with the exception of A rea ?, are in the mountainous section where, as previously deseribed, winte: grazing is often praeticed. It appeas that in these areas the pastures are lightly grazed during the summer in order to have some growth available for winter grazing.

Light grazing, as well as very heavy grazing, results in inefficient utilization of the pasture. Very heavy grazing weakens the desirable plants and decreases the total growth. Moreover the weakened plants are likely to be crowded out by undesirable plants. On the other hand, herbage that is permitted to make a rank growth is much less palatable and nutritious than that which is more closely grazed. Relatively close grazing is also more favorable to the growth of wild white clover.

Ouly a small percentage of the farmers in the areas studied mowed their pastures regularly. In order to control rank growing weeds the pasture should be mowed when the weeds are in full bloom or shortly after. Mowing is also desirable because it clips any rank growth of grass

Table 11-Pasture management data

\begin{tabular}{|c|c|c|c|c|c|c|c|}
\hline \multirow{2}{*}{$\begin{array}{c}\text { Area } \\
\text { No. }\end{array}$} & \multirow{2}{*}{$\begin{array}{l}\text { Counties } \\
\text { mainly } \\
\text { represented } \\
\text { in area }\end{array}$} & \multicolumn{3}{|c|}{$\begin{array}{c}\text { Intensity of grazing } \\
\text { (Percertage } \\
\text { distribuion) }\end{array}$} & \multicolumn{2}{|c|}{$\begin{array}{l}\text { Approximate age } \\
\text { of pasture } \\
\text { (years) }\end{array}$} & \multirow{2}{*}{$\begin{array}{l}\text { Areas } \\
\text { treated } \\
(\% \text { of } \\
\text { total }) * *\end{array}$} \\
\hline & & $\begin{array}{c}\text { Light } \\
(\%)\end{array}$ & $\begin{array}{c}\text { Medium } \\
(\%)\end{array}$ & $\begin{array}{c}\text { Heavy } \\
(\%)\end{array}$ & Average & $\begin{array}{l}\text { Genera.] } \\
\text { range* }\end{array}$ & \\
\hline 1 & Jackson & 16 & 64 & 20 & 36 & $22-50$ & $<1$ \\
\hline 2 & Ritchie & 13 & 81 & 6 & 35 & $24-46$ & $<1$ \\
\hline 3 & Monongalia & 11 & 45 & 44 & $\{9$ & $10-48$ & 23 \\
\hline 4 & Harrison & 11 & $\$ 1$ & 8 & 41 & $22-60$ & 4 \\
\hline 5 & Marshall & 13 & 62 & 25 & 25 & $11-47$ & 4 \\
\hline 6 & $\begin{array}{l}\text { Pendleton } \\
\text { Hardy }\end{array}$ & 34 & 59 & 7 & 41 & 21.61 & 1 \\
\hline 7 & $\begin{array}{l}\text { Randolph } \\
\text { Pocahontas }\end{array}$ & 54 & 41 & 6 & 34 & $17-51$ & $<1$ \\
\hline 8 & $\begin{array}{l}\text { Monroe } \\
\text { Greenbrier }\end{array}$ & 41 & 39 & 20 & 32 & $17-47$ & 18 \\
\hline 9 & $\begin{array}{l}\text { Jefferson } \\
\text { Berkeley }\end{array}$ & 29 & 41 & 30 & 23 & $8-38$ & 46 \\
\hline Aver & ge (weighted) & 27 & 59 & 14 & 35 & $\ldots$ & 7 \\
\hline
\end{tabular}

* Range in which two-thirds of pastures fall.

**Of the total area treated, $65 \%$ receired manure alone, $23 \%$ lime alone, $4 \%$ commercial fertilizer, and $8 \%$ lime plus manure or fertilizer. 
and results in more nniforn waring and therefore in more effieient utilization of the pasture.

Many of the permanent pastures of the state have been in pasture for a number of year's. The average age of the pastures in the different areas is shown in Table 11 . It will be noted that in most of the areas the average age is from about 30 to 40 rears. In three of the areas, however (Nos. 3, 5, and 9), the average age is less than 30 years, and quite a few pastures are only about 10 years old. This is true particularly of the Jefferson-Berkeley county a ea, where the land is less rolling, and where many pastures are occasionally plowed and used for harvested crops.

The practice of keeping pastures on the same land for many years without plowing is undoubtedly a good one for most of the areas studied. Many pastures, as will be seen later, are on soils of relatively steep topography and camnot be plowed and used for most harvested erops withont serious losses from soil erosion. On the smoother pastures such as are found particularly in the Jefferson-Berteley county area (Area 9) and the Greenbrier Talley (Area S), howerer, the plowing of the pastures may oecasionally be found desirable in the reestablishment of a good sod.

In spite of the long period of years that most of the land has been in pasture, very little attention has been given to replenishing the fertility of the soils by merns of lime, manure, and fertilizers. This is shown in the last column of Table 11 . Less than $7 \%$ of the total pasture area studied has been given any soil treatment.*

\section{Soil Corditions in the Different Areas}

The differences in the carrying capacity and the kind of regetation of different pastures ard pasture areas can be explained largely by soil differences. Not only do soils difer in theil inherent productivity as described on pages $S_{0}$, 2 , but the changes that have taken place sinee they were brought inco cultivation or pasture have eaused differences in productivity. The two soil factors that have been most responsible for these changes are the loss of plant food elenents by plant remoral and leaching and the los of topsoil by el'osion.

\section{Soil Acidity and Lime Requirement}

The soils of zach area were grouped on the basis of differences in the degree of acility, i.e., pHI values. $\dagger$ It will be seen in column 3 of Table 12 that a considerable percentage of the soils in some of the areas is below pH 5.0, or very strongly acid. Thus in Areas, 3, 5, and 7 over a third of the soils fall in this very strongly acid group. The highest

* Since the field work of this study has been completed, a number of farmers have become intorested in pasture improvement work, and lime and superphosphate have been used on a considerble number of pastures.

$\uparrow p H$ value r fers to degrees of ccidity. A soil of pH 7.0 is neutral, whereas solls with pH vilues below 7.0 are acid. The lower the pH value, the higher the acidity. Very asid soils have pll values below 5.0. (Most soils in West Virginia range from pH values slightly below 5.0 to $\mathrm{pH}$ values of about 6.0 ). 
pereentage of the soils in most of the arcas is of strong acidity or falls in the group of $\mathrm{pH} 5.0$ to $\mathrm{pH} 5.4$. Thirty-six percent of all the soils studierd are in this group; and $29 \%$ in the group of medium acidity, pH 5.4 to 5.8 .

Soils of pH 5.8 or above were found generally to support a good stand of Kentucky bluegrass and white clover, provided the available phosphorus was adequate and other conditions were favorable. This is shown in Figure 5. Of the total area of soils above pH 5.80 and containing over 10 pounds per acre of readily available phosphorus, $66 \%$, supported a better than 50\% stand of Kentucky bluegrass and white clover. * As contrasted to this, only $28 \%$ of the soils with pH below 5.4 had any appreciable amounts of these species.** These results are in

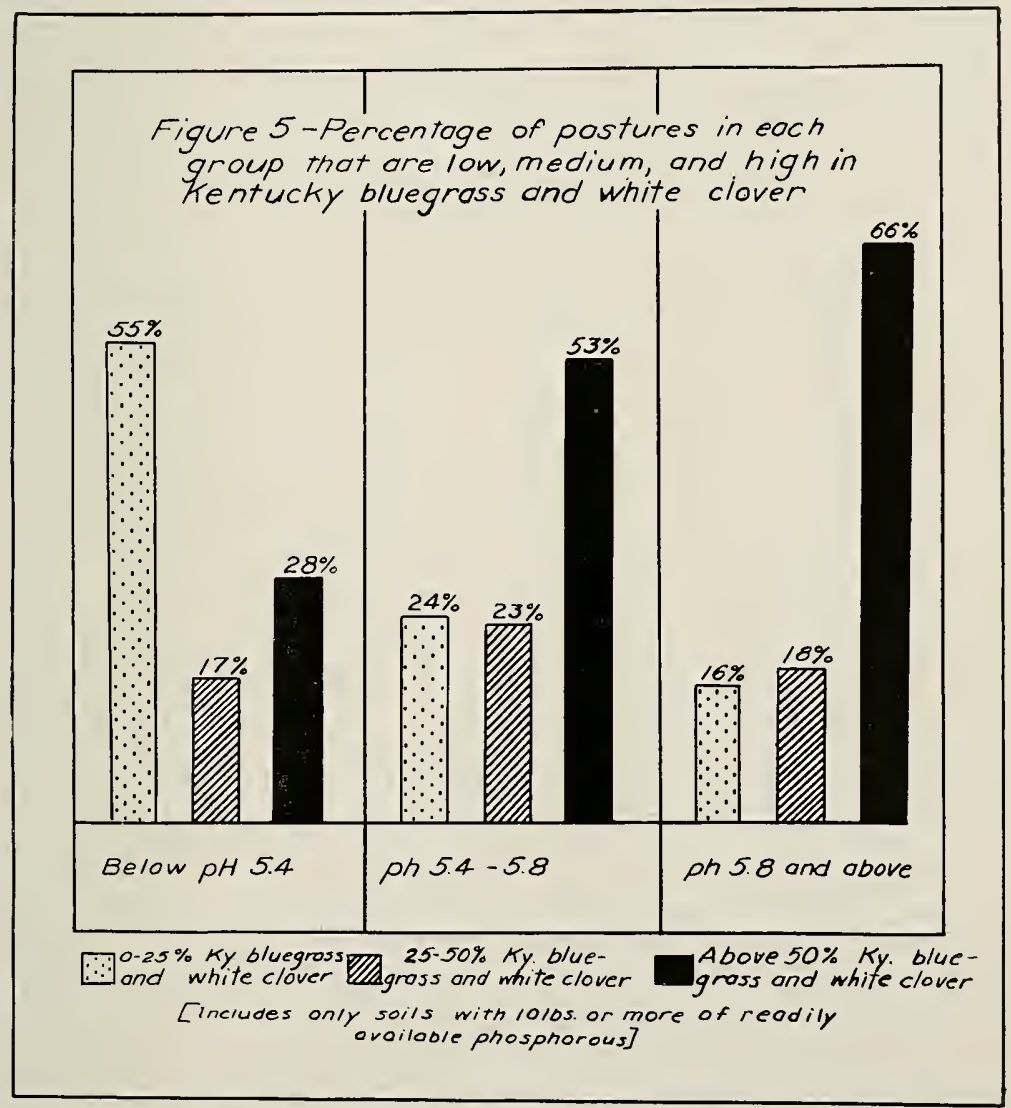

* Soils containing only 10 lbs, available phosphorus per acre are considered deficient in available phosphorus, but it was necessary to include all such soils in order to have a sufficient number for the comparisons.

** Most of the soils of below pH 5.4 that supported a good stand of bluegrass and white clover (a stand of $50 \%$ or better) were found to have a relatively high percentage base saturation. Such soils nearly always contained a high amount of organic matter. 
general agreement with those obtained in pasture experimental work eonducted at the Agrieultural Experiment Station during the past seven years, mamely, that soils of $\mathrm{pH} 5.8$ or above will support a good growth of Kentueky bluegrass and clover if other conditions are satisfactory. As shown in 'Table 12, however, only a small pereentage of the soils of most areas is in this elass. The exceptions are Area 6 (Hardy and Pendleton eounties), where $47 \%$ of the area was not in need of lime for pasture. and Area 9 , where $84 \%$ of the pasture soils likewise had $\mathrm{pH}$ values above 5.8 and was not in need of lime.

The next to the last columm of Table 12 shows the pereentage of each area in need of lime. It will be seen that over $90 \%$ of the soils of Areas $1,2,4$, and 7 are in need of lime, and that the average of all pasture areas studied is $85 \%$. Of the soils in need of lime in each area the lime requirement expressed as pure, finely-ground limestone or its equivalent l'anges from an average of $3 / 4$ of a ton per acre in the Jeff'erson-Berkeley county area to nearly $11 / 4$ tons in the Marshall eounty area (last columm,

Table 12-Soil acidity and lime needs in the different pasture areas*

\begin{tabular}{|c|c|c|c|c|c|c|c|}
\hline \multirow[b]{2}{*}{$\begin{array}{c}\text { Area } \\
\text { No. }\end{array}$} & \multirow[b]{2}{*}{$\begin{array}{l}\text { Counties } \\
\text { mainly } \\
\text { represented } \\
\text { in area }\end{array}$} & \multicolumn{4}{|c|}{ Percentage of total area } & \multirow[b]{2}{*}{$\begin{array}{l}\text { Area in } \\
\text { need of } \\
\text { lime ( } \% \\
\text { of total) }\end{array}$} & \multirow[b]{2}{*}{$\begin{array}{l}\text { Average } \\
\text { lime } \\
\text { require- } \\
\text { ment** }\end{array}$} \\
\hline & & $\begin{array}{l}\text { Below } \\
\text { pH } 5.0\end{array}$ & $\begin{array}{c}\text { Between } \\
\text { pH } 5.0 \\
\text { and } 5.4\end{array}$ & $\begin{array}{l}\text { Between } \\
\text { pIf } 5.4 \\
\text { and } 5.8\end{array}$ & $\begin{array}{l}\mathrm{pH} 5.8 \\
\text { and } \\
\text { above }\end{array}$ & & \\
\hline 1 & Jackson & 4 & 66 & 22 & S & 92 & 0.91 \\
\hline 2 & Ritchie & 7 & 58 & 35 & $<1$ & 99 & $0 . S S$ \\
\hline 3 & Monongalia & 35 & 20 & 31 & 14 & 86 & 1.02 \\
\hline 4 & Harrison & 20 & 59 & 20 & 1 & 99 & 1.00 \\
\hline 5 & Marshall & 37 & 41 & 6 & 16 & 84 & $1.1 \mathrm{~s}$ \\
\hline 6 & $\begin{array}{l}\text { Hardy } \\
\text { Pendleton }\end{array}$ & 4 & 23 & 26 & 47 & 53 & 0.80 \\
\hline 7 & $\begin{array}{l}\text { Randolph } \\
\text { Pocahontas }\end{array}$ & 37 & 15 & 45 & 3 & 97 & 1.04 \\
\hline 8 & $\begin{array}{l}\text { Monroe } \\
\text { Greenbrier }\end{array}$ & 2 & 46 & 30 & 22 & $7 \mathrm{~S}$ & 0.80 \\
\hline 9 & $\begin{array}{l}\text { Jefferson } \\
\text { Berkeley }\end{array}$ & 0 & 8 & s & 84 & 16 & 0.75 \\
\hline Ave & se (weighted) & 20 & 36 & 29 & 15 & 85 & 0.95 \\
\hline
\end{tabular}

* Data are for the soils of the open pastures from which representative sam. ples were obtained.

**Includes only the soils in need of lime, expressed as tons of pure, finely ground limestone per acre. 
Table 12). $\dagger$ These amounts seem small when compared with the amounts of lime required to grow such crops as alfalfa. The reason for these seemingly low values is twofold. In the first place, Kentucky bluegrass and white clover, which are generally found in good pastures, do not require as much lime for their successful growth as do such plants as alfalfa and sweet clover, but grow well at $\mathrm{pH}$ values of about 5.8 and above. Secondly, the lime requirement values given are based on liming only the surface three inches of soil. Experimental work has shown that a large portion of the roots are in this layer and that lime moves down into the soil very slowly when applied as a topdressing to permanent pastures. On a heavy silt loam soil at Morgantown, for example, practically all of the lime was in the 0-to-3-inch layer four years after being applied. The lime requirement values given should, however, be considered the minimum amounts needed. If legumes of high lime requirement are sown in the pasture more lime will, of course, be needed. Moreover, where the soil is low in organic matter and where lime is inexpensive, an additional half ton per acre might well be used.

\section{Readily Available Soil Phosphorus}

The amounts of readily available phosphorus were determined by the Truog laboratory test. As the term indicates, the phosphorus shown by this test does not represent the total amount available to plants, but only that portion which is readily available.

The data obtained in this study indicate that on the basis of this test at least 20 pounds of readily available phosphorus per acre are necessary if permanent pastures in West Virginia are to maintain a sod of Kentucky bluegrass and white clover. Soils with 10 to 20 pounds can be considered deficient in available phosphorus and those with less than 10 pounds as very defieient. This is well illustrated in Figure 6. Of the group of pasture soils containing less than 10 pounds of available phosphorus, $69 \%$ had less than a $25 \%$ stand of Kentucky bluegrass and white clover, and only $20 \%$ had more than a $50 \%$ stand of bluegrass and clover. On the other hand, of the group of pasture soils containing more than 20 pounds of available phosphorus per acre, only $13 \%$ had less than a $25 \%$ stand of bluegrass and clover, and $72 \%$ had more than a $50 \%$ stand.*

TThe lime requirement values were calculated from the $\mathrm{pH}$ values, and refer to the approximate amounts of ground limestone of $100 \%$ arailability required to bring the surface three inches of soil to pH 5.8. Since most of the soils were of silt loam to clay loam texture, the conversion values used were as follows: for soils of pH values below 5.0, a lime requirement of $1 \frac{1 / 2}{2}$ tons per acre; for soils between $\mathrm{pH} 5.0$ and 5.4 , a lime requirement of one ton per acre; and for soils between $\mathrm{pH} 5.4$ and 5.8 , a lime requirement of $1 / 2$ ton per acre.

*As pointed out by Truog, the minimum amount of available phosphorus that is adequate for crop production varies with the climate, the soils and the crops grown. For general farm crops under West Virginia conditions, preliminary work at this station indicates that a minimum of 40 pounds of readily available phosphorus is necessary. There is an indication from these studies that soils high in organic matter, as were many of these pasture soils, will support a good sod with a lower amount of readily available phosphorus than soils low in organic matter. This may explain the good growth of pastures on some soils that are relatively low in available phosphorus. 
I summary of the amounts of readily available soil phosphorus in the different pasture areas is given in Table 13. It will be seen from this table that a large pereentage of the soils, or an average of $77 \%$ has less than 10 pounds of available phosphorus per acre. In addition, an average of $17 \%$ of all soils has between 10 and 20 pounds of available phosphorus. This means that $94 \%$ of the pasture area studied is deficient in available phosphorus and therefore in need of phosphorus fertilizer. It should, of course, not be concluded that the remaining $6 \%$ or those soils containing 20 pounds or more of available phosphorus would not respond to phosphor us fertilizer, for' a profitable response may be obtained ever on such soils. Other factors being the same, however, the response would not be as great as on soils with less than 20 pounds of available phosphor'us.

As might be expected, the nine areas differ eonsiderably in available phosphorus. The areas most deficient are Nos. 1, 2, and 4 . Over $95 \%$ of the pasture soils of these areas have less than 10 pounds of available phosphorus per acre. It is interesting to note, also, that these areas are the lowest in desirable pasture species (Table 9). Areas 3, 5, and 9

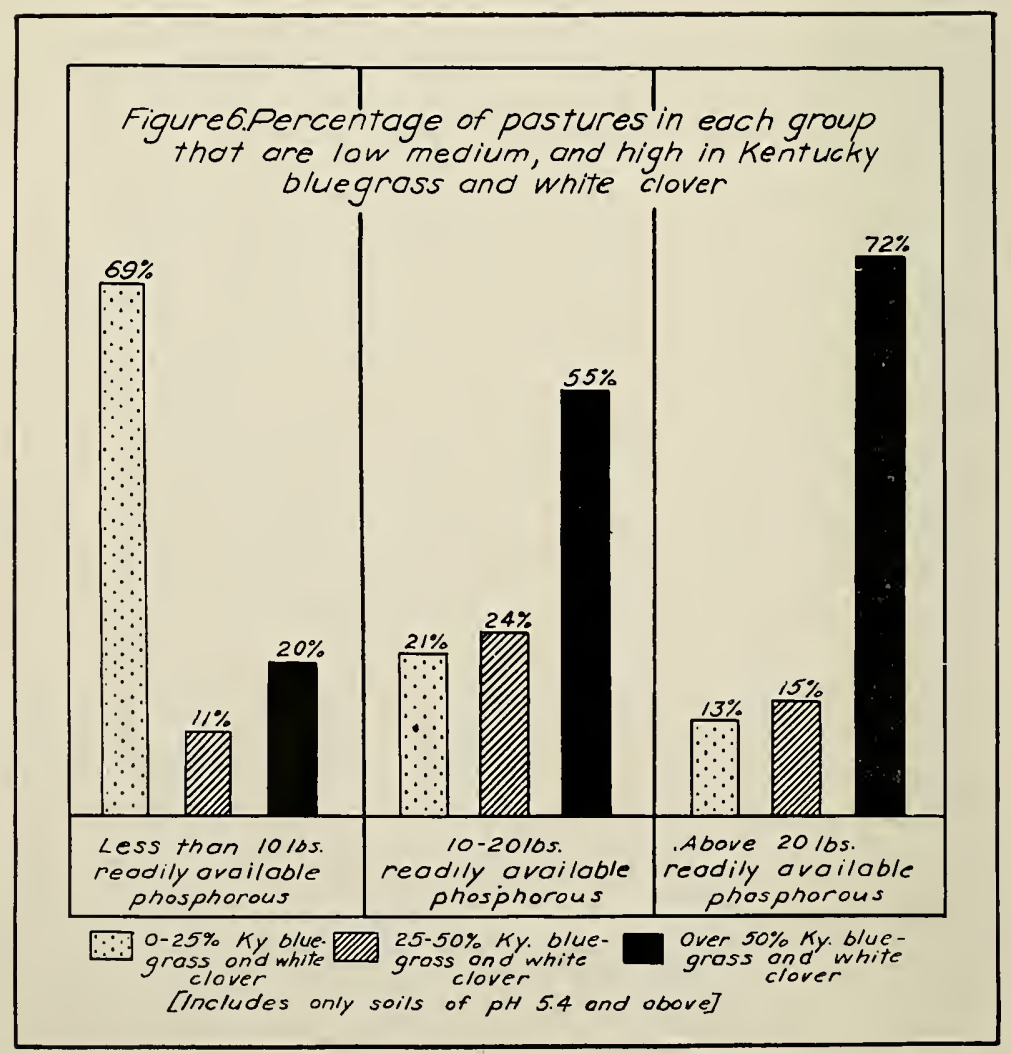


show the least deficiency in available phosphorus; and it is significant that these three areas are the only ones representing dairy sections (Table 6). Not only do dairy farmer's return more manure to their pastures, but they often feed coneentrates high in phosphorus; and a part of this phosphorus no doubt is earried to the pastures in the droppings. Even in the best of these dairy farming areas, however, over $40 \%$ of the soils were found to be very defieient in available phosphorus.

It is evident from these data, therefore, that phosphate fertilizers, as well as lime, are very essential in any program for the improvement of West Virginia pastures.

\section{Soil Erosion}

The pereentages of the soils in each area that have undergone different degrees of erosion, and the average depth of surface soil are shown

Table 13-Readily available phosphorus in the soils of the various pasture areas* (According to Truog's laboratory method)

\begin{tabular}{|c|c|c|c|c|c|}
\hline \multirow[b]{2}{*}{$\begin{array}{l}\text { Area } \\
\text { No. }\end{array}$} & \multirow{2}{*}{$\begin{array}{l}\text { Counties } \\
\text { mainly } \\
\text { represented } \\
\text { in area }\end{array}$} & \multicolumn{3}{|c|}{$\begin{array}{c}\text { Percentage of total area in different } \\
\text { classes }\end{array}$} & \multirow{2}{*}{$\begin{array}{c}\text { Percentage } \\
\text { of area } \\
\text { showing } \\
\text { phosphorus } \\
\text { deficiency }\end{array}$} \\
\hline & & $\begin{array}{c}\text { Less than } \\
10 \text { lb. } \\
\text { available } \\
\text { phosploorus }\end{array}$ & $\begin{array}{c}10-20 \text { ib. } \\
\text { available } \\
\text { phosphorus }\end{array}$ & $\begin{array}{c}\text { More than } \\
20 \text { lb. } \\
\text { available } \\
\text { phosphorus } \\
\end{array}$ & \\
\hline 1 & Jackson & 97 & 3 & $<1$ & 100 \\
\hline 2 & Ritchie & 95 & 5 & $<1$ & 100 \\
\hline 3 & Monongalia & 58 & 21 & 21 & 79 \\
\hline 4 & Harrison & 61 & 38 & 1 & 99 \\
\hline 5 & Marshall & 49 & 31 & 20 & 80 \\
\hline 6 & $\begin{array}{l}\text { Hardy } \\
\text { Pendleton }\end{array}$ & 65 & 15 & 20 & $\$ 0$ \\
\hline 7 & $\begin{array}{l}\text { Randolph } \\
\text { Pocahontas }\end{array}$ & 99 & 1 & $<1$ & 100 \\
\hline 8 & $\begin{array}{l}\text { Monroe } \\
\text { Greenbrier }\end{array}$ & 70 & 23 & 7 & 93 \\
\hline 9 & $\begin{array}{l}\text { Jefferson } \\
\text { Berkeley }\end{array}$ & 43 & 45 & 12 & S\& \\
\hline Ave & re (weighted) & 77 & 17 & 6 & 34 \\
\hline
\end{tabular}

* Data are for the solls of the open pastures from which representative sam. ples were obtained.

The amounts of readily available phosphorus are expressed as pounds per 2,000,000 pounds of soil. For convenience they shall be referred to as pounds per acre, although, the surface three inches of soil represented by these samples is undoubtedly higher in available plosphorus than the next three- to four-inch layer. 
in Table 14. Althongh the elassification used is rather general, the results obtained emphasize the large amount of erosion that has occurred in these pasture soils. Only about $3.8 \%$ of the total pasture area studied was estimated to be free from erosion. A large majority of most areas has suffered medium erosion or has lost somewhere between 25 and $75 \%$ of the original topsoil. Of the total area studied, $71 \%$ has suffered medium erosion. Moreover, $15 \%$ of all areas has suffered severe erosion or has lost more than $75 \%$ of the topsoil. The greatest loss of surface soil by erosion was found in Area 2. In this area $46 \%$ of the soils has undergone severe erosion and the average depth of top soil is only 2.8 inches. In marked eontrast to this are the values for Area 9 (Jefferson and Berkeley counties), where only $2 \%$ of the soils are severely eroded and the topsoil averages 7.4 inches in depth.

The differences in the amount of erosion that has taken place in the different pasture areas is determined largely by the steepness of the slopes, the soil type, the previous treatment of the soils, and the kind of sod present. A large part of the land in pastures was at one time or other in harvested erops before turning to pasture. This means that

Table 14-Soil erosion in the non-woodland pastures of the different areas*

\begin{tabular}{|c|c|c|c|c|c|c|}
\hline \multirow[b]{2}{*}{$\begin{array}{c}\text { Area } \\
\text { No. }\end{array}$} & \multirow{2}{*}{$\begin{array}{l}\text { Counties } \\
\text { mainly } \\
\text { represented } \\
\text { in area }\end{array}$} & \multicolumn{4}{|c|}{ Percentage of total acreage } & \multirow{2}{*}{$\begin{array}{l}\text { Average } \\
\text { depth of } \\
\text { topsoil } \\
\text { (inches) }\end{array}$} \\
\hline & & $\begin{array}{c}\text { No } \\
\text { erosion }\end{array}$ & $\begin{array}{l}\text { Slight } \\
\text { erosion }\end{array}$ & $\begin{array}{l}\text { Medium } \\
\text { erosion }\end{array}$ & $\begin{array}{l}\text { Severe } \\
\text { erosion }\end{array}$ & \\
\hline 1 & Jackson & 2 & 2 & 81 & 15 & 4.8 \\
\hline 2 & Ritchie & $<1$ & $<1$ & 53 & 46 & 2.8 \\
\hline 3 & Monongalia & $<1$ & 14 & $\$ 3$ & 3 & 5.4 \\
\hline 4 & Harrison & 2 & 11 & 70 & 17 & 4.4 \\
\hline 5 & Marshall & $<1$ & 7 & so & 13 & 5.1 \\
\hline 6 & $\begin{array}{l}\text { Pendleton } \\
\text { Hardy }\end{array}$ & 13 & s & 61 & 16 & 4.3 \\
\hline 7 & $\begin{array}{l}\text { Randolph } \\
\text { Pocahontas }\end{array}$ & 5 & 21 & 71 & 3 & 7.3 \\
\hline 8 & $\begin{array}{l}\text { Greenbrier } \\
\text { Monroe }\end{array}$ & 2 & $<1$ & 90 & 8 & 5.7 \\
\hline 9 & $\begin{array}{l}\text { Jefferson } \\
\text { Berkeley }\end{array}$ & 12 & 25 & 61 & 2 & 7.4 \\
\hline \multicolumn{2}{|c|}{ Average (weighted) } & 4 & 10 & 71 & 15 & .. \\
\hline
\end{tabular}

*Slight erosion-Less than $25 \%$ of original soil lost.

Medium erosion-Between 25 and $75 \%$ or original soil lost.

Severe erosion-More than $75 \%$ or original soil lost. 
many of the pastures were started on soils already eroded and depleted in fertility. Moreover there has been a continual removal of fertility from the soil by the grazing animals as well as by leaching, and very few of the pastures have received any manure, fertilizer, or lime. The result is that pastures are gradually becoming poorer. The bare space in many pastures now amounts to over $30 \%$. Because of the large amount of bar soil present, much sheet erosion is taking place on the steeper slopes, and in many pastures gullies of various sizes are developing. Thus a vicious eycle continues. As a greater amount of erosion takes plaee, the fertility of the soil rapidly decreases, the vegetation becomes poorer, and erosion continues at increasing rates. Soon a point is reached in this eycle when so mueh of the surface soil has been lost that the pastures can no longer be improved eeonomically. Lime and fertilizers will no doubt help on such badly-eroded pastures but there is considerable question as to whether the treatment will be economical, for the soil no longer has the water-holding capacity and organic matter content necessary for good yields. Unfortunately, some of the pastures studied are already past the point where improvement seems practieable.

Table 15-Slope of the non-woodland pastures in the different areas

\begin{tabular}{|c|c|c|c|c|c|}
\hline \multirow[b]{2}{*}{$\begin{array}{c}\text { Area } \\
\text { No. }\end{array}$} & \multirow{2}{*}{$\begin{array}{l}\text { Counties } \\
\text { mainly } \\
\text { represented } \\
\text { in area }\end{array}$} & \multicolumn{3}{|c|}{ Percentage of total acreage } & \multirow{2}{*}{$\begin{array}{l}\text { Estimated } \\
\text { area not } \\
\text { worth } \\
\text { improving* } \\
\text { (\% of total) }\end{array}$} \\
\hline & & $\begin{array}{l}0 \text { to } 25 \% \\
\text { slope }\end{array}$ & $\begin{array}{l}25 \text { to } 40 \% \\
\text { slope }\end{array}$ & $\begin{array}{l}\text { Above } \\
40 \% \\
\text { slope }\end{array}$ & \\
\hline 1 & Jackson & 55 & $2 S$ & 17 & 36 \\
\hline 2 & Ritchie & 22 & 45 & 33 & 52 \\
\hline 3 & Mronongalia & 59 & 30 & 11 & 27 \\
\hline 4 & Harrison & 35 & 49 & 16 & 23 \\
\hline 5 & Marshall & 43 & 41 & 16 & 23 \\
\hline 6 & $\begin{array}{l}\text { Pendleton } \\
\text { Fardy }\end{array}$ & 72 & 19 & 9 & 27 \\
\hline 7 & $\begin{array}{l}\text { Randolph } \\
\text { Pocahontas }\end{array}$ & 48 & 34 & 18 & 19 \\
\hline 8 & $\begin{array}{l}\text { Greenbrier } \\
\text { Monroe }\end{array}$ & 82 & 15 & 3 & 10 \\
\hline 9 & $\begin{array}{l}\text { Jefferson } \\
\text { Berkeley }\end{array}$ & 100 & $<1$ & 0 & $<1$ \\
\hline Ave & ge (weighted) & 51 & 33 & 16 & 25 \\
\hline
\end{tabular}

*Total of all areas above $40 \%$ slope and of areas with less than $40 \%$ slope where improvement seems impractical. These areas should be in trees. 
In contrast to the eonditions which exist on pastures that have a poor sod, a good sod is one of the best means of preventing soil erosion, as the work of the Soil Conservation Service well shows. Moreorer, a good pasture sod means that a high pereentage of the rain is absorber by the soil and becomes available for increased plant growth.

\section{Slope}

Slope is an important factor in determining not only the amount of erosion that takes place but also the extent to which pasture improvement is practicable. It seemed important therefore to obtain definite information on the lopography or slope of the pasture soils in the different areas. The percentage of each pasture area in different slope elasses is shown in Table 15 . In general slopes of less than $25 \%$ are well suited to pastures. (A slope of $25 \%$ has a vertical rise of 25 feet for each 100 fect of horizontal distance.) As shown in column 3 , however, four of the areas studied have less than $50 \%$ of their acreage in this slope class. Of the remaining five, the two principal limestone areas (Nos. 8 and 9 ) had the largest percentage of soil of 0 to $25 \%$ slope, namely, 82 and $100 \%$ respectively. The average for all areas is $51 \%$.

Soils with 25 to $40 \%$ slope generally are also suited to pastures. However, where erosion has been severe and where the fertility of the soil is low, soils of this slope, particularly those near the upper slope value, cannot be improved profitably and must eventually be retumed to woods. The pereentage of soils in the 25 to $40 \%$ slope class varies from less than $1 \%$ in Area 9 to over $40 \%$ in Areas 2, 4, and 5; and the average for all areas is $33 \%$.

In all areas but one. some of the pastures have slopes of over $40 \%$. Soils on such slopes erode easily and are not suited to pastures. In the Ritchie county area $33 \%$ of the pasture area has a slope of over $40 \%$, and in five of the remaining areas 10 to $18 \%$ of the pasture areas studier have slopes of over $40 \%$. The average for the total pasture aereage is $16 \%$.

\section{Percentage of Pasture Areas Not Suitable for Improvement}

Many of the pastures of the state are so badly eroded or are on such: steep slopes that improvement by the re-establishment of a bluegrassclover sod through the use of lime and phosphorus is not practieal or economieal. Other things being equal, the greater the slope, the larger the proportion of the rainfall which runs off from the surface. Not only does this run-off earry with it the valuable topsoil, but it means also that less water is absorbed by the soil to furnish water to the plants. Plants. therefore, often suffer from drought on steep slopes, and poor plant growth results. For that reason the response from fertilization and liming may not be economical on soils of a high degree of slope. Moreoves, implovement of steep slopes is often not practical because it is difficult, if not impossible, to spread fertilizer, manure, and lime with machinery. 
In the last column of the table (Table 15) are given the estimated percentages of the total pasture areas that are not suited for pastures. This estimate inchudes all areas of over $40 \%$ slope as well as areas below $40 \%$ slope that have been so damaged by erosion or are so poor that improvement would not seem to be economical or practicable. The jercentages vary from less than $1 \%$ in the Jefferson-Berkeley county area to over $50 \%$ in the Ritchie county area, and the average for the total pasture area studied is $25 \%$. For the state as a whole it is estimater that at least one-third of the pastures are so steep or so badly eroded that fertilization and liming cannot be recommended. Additional studies may show that an even larger pereentage than this camnot be improver economicaily, espeeially if the pastures are allowed to deteriorate finther before improvement is started.

\section{Comparison of Different Areas}

In order to better compare the different areas as regards soil and pasture conditions, some of the more important data were brought together. These data are given in Table 16, the areas being listed in the order of increasing amounts of desirable species in the pasture.

The Ritchie county area, which as previously mentioned consist:; mostly of Meigs and Dekalb soils, has the lowest percentage of desirable pasture plants of any of the areas studied. Likewise, it ranks lowest in

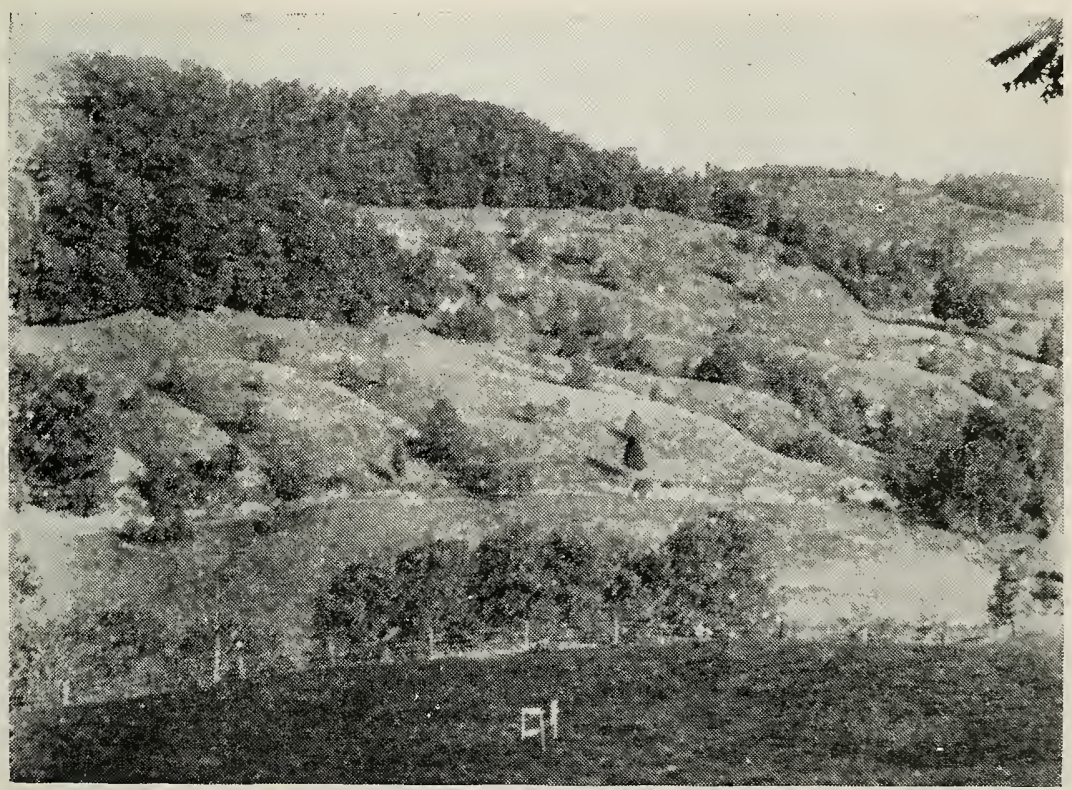

A pasture on eroded Meigs clay loam, where treatment with lime and fertilizer is impractical. Such land should be in trees. 
earrying eapacity as well as in favorable soil characteristics. Practically all the soils are in need of lime and are very deficient in available phosphorus. Moreover, nearly one-third of the pastures are on slopes of over $40 \%$, and $46 \%$ of the area studied is severely eroded. This means that approximately one-half of the pasture area can not be improved economieally and is therefore not suited for pastures. It should be returned to forest as soon as possible. Although these data apply mostly to the pastures of Ritchie county, from which most of the farms were selected, they are believed to be typical of the pastures on much of the Meigs soils in the west central part of the state. Parts of Lewis and Upshur comnties have pasture conditions more typical of the Harrison county area.

The Jackison county area, which represents mostly Upshur soils, is also very low in desirable species. The earrying capacity of this area is found to be somewhat higher than of Area 2. This may be accounted for partly by the better general topography and lower amount of erosion. The carrying eapacity given, however, may be too high, since many of

Table 16-Summary data of pasture conditions in the different areast

\begin{tabular}{|c|c|c|c|c|c|c|c|c|}
\hline \multirow[b]{2}{*}{$\begin{array}{c}\text { Area } \\
\text { No. }\end{array}$} & \multirow[b]{2}{*}{$\begin{array}{l}\text { Counties } \\
\text { mainly } \\
\text { represented } \\
\text { in area }\end{array}$} & \multirow[b]{2}{*}{$\begin{array}{l}\text { Stand } \\
\text { of de- } \\
\text { sirable } \\
\text { plants } \\
(\%)\end{array}$} & \multirow[b]{2}{*}{$\begin{array}{l}\text { Acres } \\
\text { per } \\
\text { animal } \\
\text { unic }\end{array}$} & \multicolumn{5}{|c|}{ Percentage of total area } \\
\hline & & & & $\begin{array}{c}\text { Severe- } \\
\text { ly } \\
\text { eroded }\end{array}$ & $\begin{array}{l}\text { Over } \\
40 \% \\
\text { slope }\end{array}$ & $\begin{array}{l}\text { Not } \\
\text { suited } \\
\text { for } \\
\text { pas- } \\
\text { ture }\end{array}$ & $\begin{array}{l}\text { In } \\
\text { need } \\
\text { of } \\
\text { lime* }\end{array}$ & \begin{tabular}{|c|} 
Very \\
defi- \\
cient in \\
phos- \\
phorus**
\end{tabular} \\
\hline 2 & Ritchie & 11 & 5.3 & 46 & 33 & 52 & 99 & 95 \\
\hline 1 & Jackson & 14 & 4.4 & 15 & 17 & 36 & 92 & 97 \\
\hline 4 & Harrison & 20 & 5.0 & 17 & 16 & 23 & 99 & 61 \\
\hline 3 & Monongalia & 22 & 3.4 & 3 & 11 & 23 & 86 & $5 s$ \\
\hline 6 & $\begin{array}{l}\text { Pendleton } \\
\text { Hardy }\end{array}$ & 24 & 4.7 & 16 & 9 & 27 & 53 & 65 \\
\hline 7 & $\begin{array}{l}\text { Randolph } \\
\text { Pocahontas }\end{array}$ & 25 & 4.0 & 3 & 18 & 19 & 97 & 99 \\
\hline 8 & $\begin{array}{l}\text { Greenbrier } \\
\text { Monroe }\end{array}$ & 33 & 3.7 & 8 & 3 & 10 & 78 & 70 \\
\hline 5 & Marshall & $3 s$ & 3.2 & 13 & 16 & 23 & $\$ 1$ & 49 \\
\hline 9 & $\begin{array}{l}\text { Jefferson } \\
\text { Berkeley }\end{array}$ & 47 & 2.5 & 2 & 0 & $<1$ & 16 & 43 \\
\hline Ave & e (weighted) & 24 & 4.2 & 15 & 16 & 25 & 85 & 77 \\
\hline
\end{tabular}

*pH value of soil less than 5.8 .

**Less than $10 \mathrm{lb}$. per acre available phosphorus (Truog laboratory method).

† All data are based on non-woodland pasture except those in the last two columns; these are based on open-pasture areas. 
the pastures were rather heavily grazed. $\Lambda s$ in $\Lambda$ rea 2 , the soils are very defieient in available phosphorus and in lime. Approximately onethird of the area studicd is very steep or badly eroded and is not suited for pastures.

The Harison eounty area contains an average of $20 \%$ desirabie pasture plants and has an average of 5 acres of pasture per animal unit. The Westmoreland soil ehiefly represented in this area is not as badly eroded as the Meigs and Dekalb soils of Area 2. Nevertheless a total of $23 \%$ of the area is so badly eroded or is on such steep slopes that it is not suitable for pastures. The soils of this area are as badly in need of lime as those of Areas 1 and 2 , but they are somewhat less deficient in available phosphorus.

The IIonongalia area (No. 3) ranks next lowest in percentage of desirable speeies. As previously mentioned, the farms selected in this area are representative only of the dairy farms. Three and four-tenths aeres are required per animal unit. Since the pastures were very closely grazed, this value, as explained later, may be low. The area represented by these farms has suffered less severe erosion and has on the average a eonsiderably deeper topsoil than the first three areas listed. Moreover, the soils are not quite so mueh in need of lime or so defieient in available phosphorus.

The Pendlcton-Hardy area (No. 6) and the Randolph-Pocahontas arca (No. 7) are very similar in average pereentage of desirable plants in the pastures. Both areas represent valley and platean soils in the mountainous section of the state. Beeause of the large amount of woorland pasture, especially in Area 6, the carrying capaeity of the nonwoodland pasture was rather diffieult to evaluate. Aeeording to the best data available, however, it is found that abont 4 to $41 / 2$ aeres of nonwoodland pasture are required per animal unit. The soil eonditions in

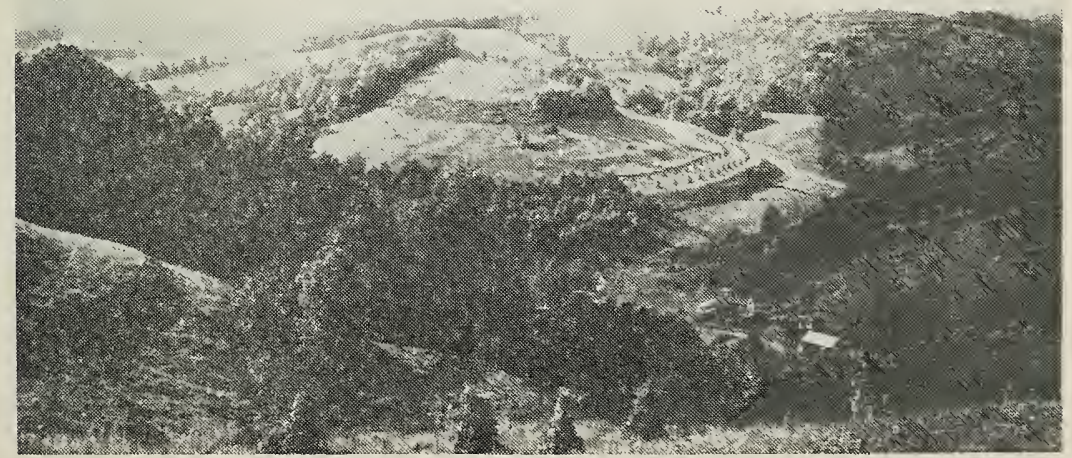

Typical topography of some of the poorer pasture areas. 
the two areas are somewhat different, although both areas contain soils varying widely in fertility and agricultural value. The Dekalb soils in Area 6 are shale loams and droughty. Because of the poor vegetation on these soils there has been considerable erosion, even though the topography is only gently rolling. On the other hand quite a high percentages of this area consists of bottomland soils and of upland soils of limestone origin. This $n 0$ doubt accounts for the fact that only $53 \%$ of the area is in need of lime for pastures, as compared to over $90 \%$ in need of lime in many of the other areas. Approximately $27 \%$ of the area now in pastures should be put back into forest.

The Randolph-Pocahontas pasture area has very little severe erosion even though $18 \%$ of it has a slope of over $40 \%$. The relatively small amount of erosion no doubt is explained by the fact that many pastures are somewhat stony and were never tilled but were turned to pasture immediately after clearing the forest. The arerage depth of soil is 7.3 inches. The soils are practically all in need of lime and are very deficient in available phosphorus. In a few pastures of the area rather good vegetation was found where the soil was fairly acid and low in available phosphorus. This condition was apparently related to the high organic matter content of these soils and to the greater rainfall and higher soil moisture. Nineteen percent of this pasture area is estimated to be too steep to be improved economically.

The Grecubrier-1Lonroe area represents only the limestone soils of the Greenbrier Valley. An average of $33 \%$ of the pasture area is occupied by desirable plant species, and an average of 3.7 acres is used to pasture one animal unit. Less than $8 \%$ of the soils have suffered severe erosion although, as shown in Table 14, there has been considerable "medium erosion". Eveli though the soils are mostly of limestone origin, $78 \%$ are in need of lime. Seventy percent of the area is rery deficient in available phosphorus.

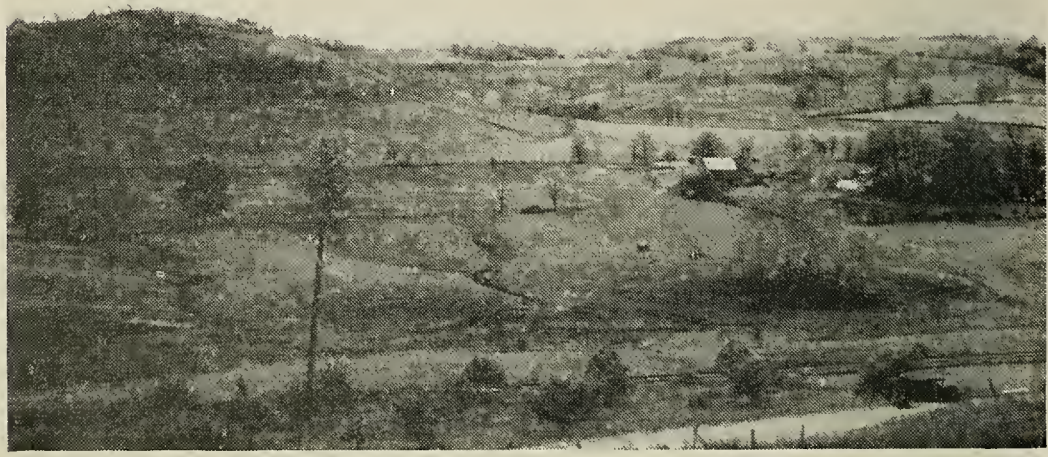

Pastures in background are on less rolling area of Upshur clay loam soil, Jackson County. Much of the pastures on such areas can be improved economical!y. 
The Marshall area, which represents mostly the Westmoreland and Brooke soils of these eounties, has a relatively high pereentage $(38 \%)$ of desirable plants in the pastures, and 3.2 acres are required to pasture one animal unit. This is in spite of the fact that $16 \%$ of the pasture area is on slopes of over $40 \%$, and that $13 \%$ of the soils are severely eroder. The soils of this area are generally in need of lime. The percentage of the soils which are very deficient in available phosphorus is not quite as low as in most of the other areas. This may be explained partly by the fact that some fertilizer had been used while the pasture land was in erops. Twenty-three pereent of the pasture area was estimated to be tho steep or badly eroded to be improved economically.

The Jefferson-Berkeley area has the highest percentage of desirable plants in the pastures of any of the areas $(47 \%)$, and the lowest number of acres of pasture ( 2.5 acres) are required per animal unit. This is not surprising when the soil data are considered. This area represents only the limestone soils of these counties, mostly Hagerstown and Huntington soils. Practically all the pastures are on slopes of less than $25 \%$. and less than $2 \%$ of the pasture soils have undergone severe erosion. Moreover, only $16 \%$ of the area is in need of lime for bluegrass pastures. As has been shown in Table 11, considerable lime has been used on pastures. Although the percentage of the soils that are very deficient in phosphorus is not as high as in the other areas (43\%), at least $88 \%$ of the area should respond profitably to phosphorus fertilization. Many of:

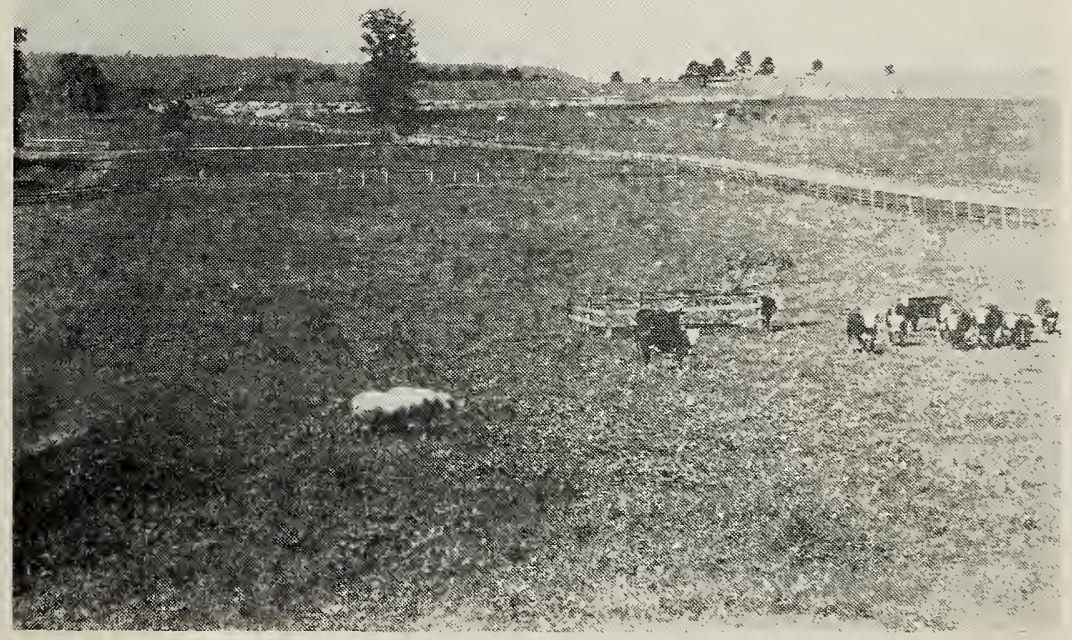

Typical pasture scene on Frankstown silt loam soil in the Greenbrier Valley, Greenbrier County. 
these pastures could support one animal unit per acre if they were treated with superphosphate and with lime when necessary.

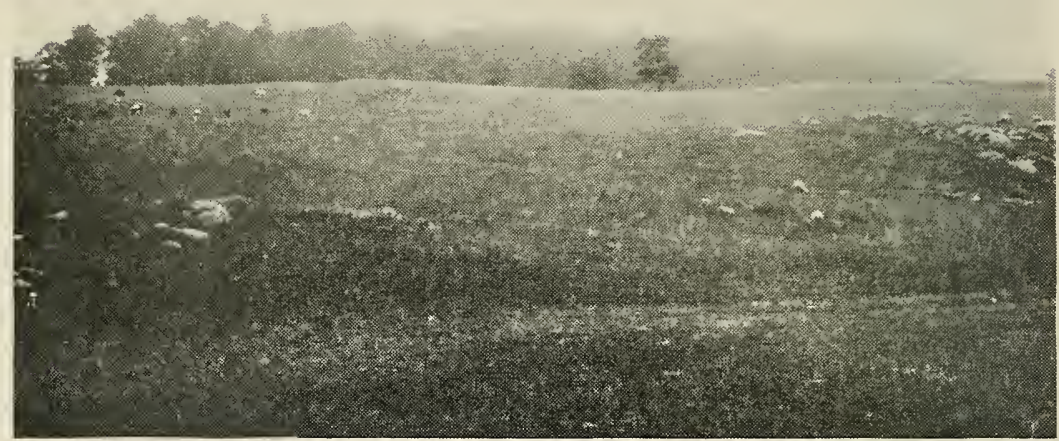

Pasture on Hagerstown silt loam in Jefferson County. Limestone outcrops are typical of many pastures in this area.

\section{Pasture Conditions as Related to Soil Type}

The data that have been presented emphasize the wide differences that exist in the average carrying capacity, type of regetation, and soil conditions in the different areas. As previously mentioned, many of the areas studied were selected because they represent different kinds of soil. All areas, however, contain more than one soil type and soil series. Jt seemed desirable, therefore, to rearrange the data according to groups of soils or soil series.*

It was found, as might be expected, that wide differences exist among the different soil series as regards the type of regetation they support, the degree of slope, the amount of soil erosion that has taken place, and the deficiencies in lime and available phosphorus. These data are shown in detail in Tables A, B, and $\mathrm{C}$ of the Appendix. Only the summary data, given in Table 17 and Figure 7, however, need to be discussed. In Figure 7 the soils are arranged in ascending order according to the amounts of desirable pasture plants they support. The order is as follows: Meigs, Dekalb, Upshur, Westmoreland, Pope and related soils, Frankstown and related soils, Hagerstown, and Huntington and related soils. The pasture on the Meigs soils, which are usually considered of relatively low productivity, average only $12.6 \%$ desirable species, whereas the Huntington group of soils averaged $44.1 \%$ The

*These soils have been described on pages $s$ tn 11 and their acreage in the different areas given in Table 3 . Most of the soils in each series consist of silt loams and clay loams. 
depth of topsoil varies in the same order, the Meigs soils averaging only 3.6 inehes and the Huntington and Moshannon soils 8.9 inches. Since the Huntington and Pope groups of soils occupy bottomlands along streams, their high average depth of topsoil is partly a result of the wash they have received from the upland soils. The IIagerstown soils average less in depth than the Frankstown and related soils. This is, no doubt, partly explained by the fact that many of the Hagerstown soils in Jefferson and Berkeley counties (Area 7) have frequently been plowed and used for corn and other harvested erops and have thus been subjected to considerable erosion.

The depth of topsoil is elosely related to the slope of the soils and the amount of erosion that has taken place. This is well shown in Figure 7. About $35 \%$ of the Meigs soils are on slopes of over $40 \%$, and $43 \%$ of the soils have suffered severe erosion or have lost $75 \%$ or more of their original topsoil. A large percentage of the Dekalb, Upshur, and Westmoreland soils also have quite rolling topography, and soil erosion has been pronounced. The Frankstown and Hagerstown soils occupy

Table 17-Summary of important soil and pasture conditions according to soil series*

\begin{tabular}{|c|c|c|c|c|c|c|c|}
\hline $\begin{array}{c}\text { Soil } \\
\text { series }\end{array}$ & $\begin{array}{l}\text { Area of } \\
\text { each } \\
\text { soil } \\
\text { (\% of } \\
\text { total) }\end{array}$ & $\begin{array}{l}\text { Desir- } \\
\text { able } \\
\text { grasses } \\
\text { and } \\
\text { legumes } \\
\text { ( } \% \text { of } \\
\text { total) }\end{array}$ & $\begin{array}{c}\text { Ave. } \\
\text { depth } \\
\text { of sur- } \\
\text { face soil } \\
\text { (in.) }\end{array}$ & $\begin{array}{l}\text { Area } \\
\text { over } \\
40 \% \\
\text { sIope } \\
\text { (\% of } \\
\text { total) }\end{array}$ & $\begin{array}{c}\text { Area } \\
\text { severe- } \\
\text { ly } \\
\text { eroded } \\
\text { (\% of } \\
\text { total) }\end{array}$ & $\begin{array}{l}\text { Area in } \\
\text { need of } \\
\text { lime } \\
(\% \text { of } \\
\text { total }) \dagger\end{array}$ & $\begin{array}{c}\text { Area } \\
\text { with less } \\
\text { than } 10 \\
\text { pounds } \\
\text { available } \\
\text { phos- } \\
\text { phorus } \\
\text { peracre } \\
\text { ( } \% \text { of } \\
\text { total) } \dagger\end{array}$ \\
\hline Delkalb & 22.5 & 18.5 & 4.1 & 19 & 21 & 84 & 71 \\
\hline Meigs & 15.6 & 12.6 & 3.6 & 35 & 43 & 98 & . 92 \\
\hline Upshur & 11.9 & 21.8 & 5.0 & 14 & 8 & 38 & 88 \\
\hline Westmoreland & 21.9 & 26.1 & 5.2 & 15 & 15 & 92 & 60 \\
\hline $\begin{array}{l}\text { Frankstown } \\
\text { Frederick } \\
\text { Lowell }\end{array}$ & 16.8 & 31.3 & 7.7 & 5 & 4 & So & 82 \\
\hline Hagerstown & 6.6 & 39.1 & 5.7 & 2 & 7 & 32 & 61 \\
\hline $\begin{array}{l}\text { Huntington } \\
\text { Moshannon }\end{array}$ & 2.3 & 44.1 & 8.9 & 0 & 0 & 64 & 58 \\
\hline $\begin{array}{l}\text { Pope } \\
\text { Atkins }\end{array}$ & 1.2 & 31.0 & 7.8 & 0 & 0 & 79 & 67 \\
\hline Miscellaneous & 1.2 & 18.2 & 7.7 & 0 & 0 & 80 & 63 \\
\hline
\end{tabular}

*All data are based on weighted averages.

TThe data in the last two columns do not represent all pastures studied, but only those pastures from which representative soil samples were talien. 
more gently rolling areas and have suffered the least erosion of the upland soils. Moreover, as shown in Table 17, the Hagerstown soils show the least need for lime and for phosphorus, whereas the Meigs soils show the greatest need.

General Relationships

Relation Between Type of Vegetation and Carrying Capacity

One of the important results obtained in this investigation is the close relationship found to exist between the percentage of desirable plant species and the carrying capacity of the pastures. This relationship, which has already been mentioned, is more definitely shown in

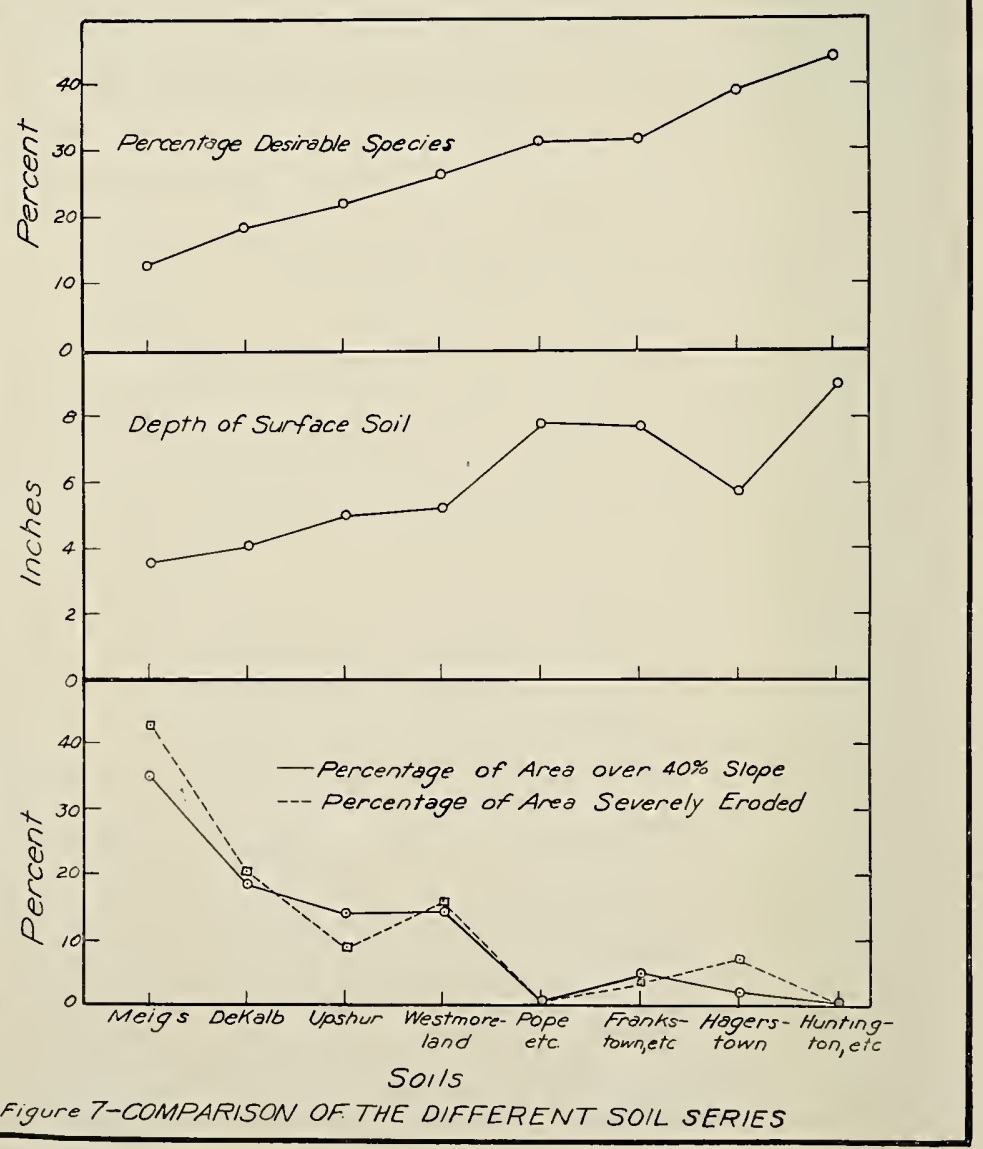

4 
Figure 8 , where the areas are arranged in order of increasing percentages of desirable species. It will be seen that as the average percentage of desirable species increases, the number of acres required to pasture one animal unit decreases. The only marked exeeption to this relation. ship is Area 3, where it took an average of 3.4 acres to pasture one animal unit, even though only $22 \%$ of the pasture area was covered with desirable species. This exception, whowever, is probably more apparent than real. As shown in Table 11, this area was more closely grazed than were the other areas which means that there was greater utilization of the herbage present.

Having obtained such a good relationship between the pereentage of desirable species and the carrying capacity of the pastures in the different areas, it seemed desirable to see if some standard could not be established that would make it possible to determine the earrying eapacity of pastures from a knowledge of the type of vegetation present. The standard that was developed on the basis of the data obtained from this study as well as from other investigations is shown in Table 18. On the basis of this standard, the carrying capacity of the pastures was ealeulated from the values of percentage of desirable species. As shown

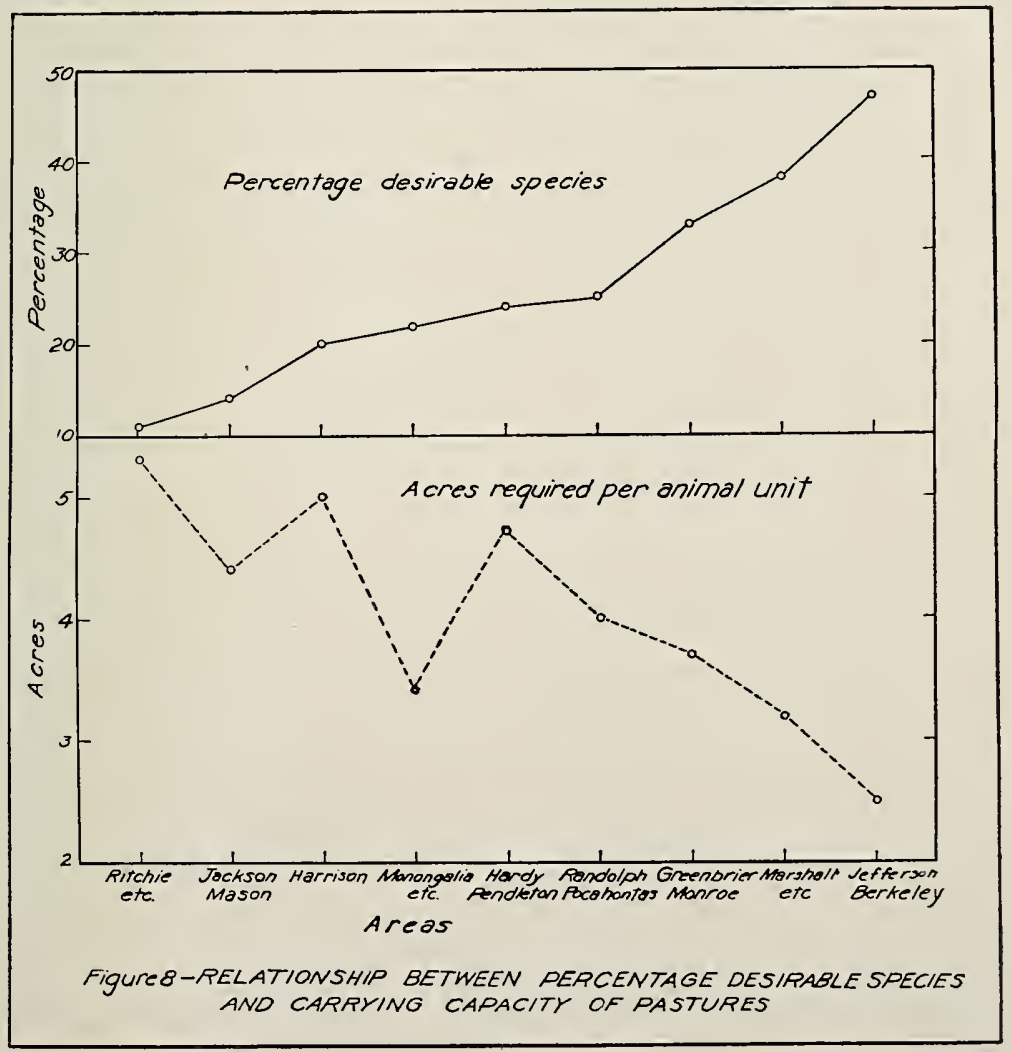


in Table 19, the average rarrying capacity per farm thus ealeulated agrees very well with the actual carrying capacity as obtained from the farmer's information.* The close agreement between the calculated and "found" values shows that for West Virginia conditions the standared given in Table 18 can be used as a good guide in evaluating the carrying capacity of different permanent pastures. The pastures that contain less than $16 \%$ of desirable species, and therefore can be considered to be poor pastures, require an avelage of 5 to 6 acres to pasture one animal unit. Fair pastures, or those containing 16 to $30 \%$ desirable species, require 3.5 to 4.5 acres to pasture one animal unit; medium pastures (31 to $50 \%$ desirable species), 2.5 to 3.25 acres; good pastures (51 to $75 \%$ desirable species), 1.25 to 2.25 acres; and excellent pastures (T6 to $100 \%$ desirable species), one acre or less to pasture one animal unit.

These data emphasize the importance of bluegrass, clover, and othei desirable species in permanent pastures. Although grazing animals eat to a certain extent the poor native grasses and weeds, these plants produce lower rields and a poorer quality of herbage, and therefore more acres of such pastures are nceessary than of bluegrass and clover pastures to support one animal unit.

The percentage of the pasture acreage in each area that can be classified as poor, fair, medium, good, or excellent is shown in Table 20. As an average for all areas studied it is found that $50 \%$ of the pastures are poor or contain less than $16 \%$ desirable species, and only about $10 \%$

Table 18-Standards for approximate evaluation of pastures based on percentage of desirable species

\begin{tabular}{|c|c|c|c|c|}
\hline \multirow[b]{2}{*}{$\begin{array}{l}\text { Rating of } \\
\text { pasture }\end{array}$} & \multicolumn{2}{|c|}{ General standard } & \multicolumn{2}{|c|}{ Detail standard } \\
\hline & $\begin{array}{c}\% \\
\text { desirable } \\
\text { species }\end{array}$ & $\begin{array}{c}\text { Acres } \\
\text { required } \\
\text { per animal } \\
\text { unit }\end{array}$ & $\begin{array}{c}\% \\
\text { desirable } \\
\text { species }\end{array}$ & $\begin{array}{c}\text { Acres per } \\
\text { animal } \\
\text { unit }\end{array}$ \\
\hline Poor & $0-15$ & 5.5 & $\begin{array}{c}0.5 \\
6-10 \\
11-15\end{array}$ & $\begin{array}{l}6.00 \\
5.50 \\
5.00\end{array}$ \\
\hline Fair & $16-30$ & 4.0 & $\begin{array}{l}16-20 \\
21-25 \\
26-30\end{array}$ & $\begin{array}{l}4.50 \\
4.00 \\
3.50\end{array}$ \\
\hline Medium & $31-50$ & 2.5 & $\begin{array}{l}31-35 \\
36-40 \\
41-45 \\
46-50\end{array}$ & $\begin{array}{l}3.25 \\
3.00 \\
2.75 \\
2.50\end{array}$ \\
\hline Good & $51-75$ & 1.5 & $\begin{array}{l}51-55 \\
513-60 \\
61-65 \\
66-70 \\
71-75\end{array}$ & $\begin{array}{l}2.25 \\
2.00 \\
1.75 \\
1.50 \\
1.25\end{array}$ \\
\hline Excellent & $76-100$ & 0.8 & $\begin{array}{l}76-85 \\
85-100\end{array}$ & $\begin{array}{l}1.00 \\
0.75\end{array}$ \\
\hline
\end{tabular}

NOTE: If slope is over $40 \%$ substract one-fourth from carrying capacity; if in bottomland, add one-fourth to carrying capacity.

*The coefficient of correlation $=0.974 \pm 0.004(n=206)$. If the two large farms (five times the average size) are omitted, $r^{*}=0.927 \pm 0.01$. 
have more than $50 \%$ desirable species or can be considered good or excellent pastures.

\section{Relation Between Type of Pasture and Acidity and Available Phosphorus Content of Soil}

Since the permanent pastures can be readily classified into different groups based on the type of vegetation present, it is of interest to see how the soils of these groups differ in acidity and available phosphorus. In Figure 9 the pastures are grouped into poor pastures, fair and medium pastures, and good and excellent pastures; and the acidity of the soils in each group is shown graphically. It is seen that $72 \%$ of the area in poor pastures consists of acid to strongly acid soils, whereas only $25 \%$ of the good and excellent pastures are on soils of this acidity ( $\mathrm{pH}$ below 5.4 ). On the other hand, only $9 \%$ of the poor pastures are not in need of lime, whereas $54 \%$ of the good and excellent pastures are on soils not in need of lime ( $\mathrm{pH} 5.8$ or above).

The available phosphorus content of the soils in the three groups is shown in Figure 10. It is seen that of the area in poor pasture, $84 \%$

Table 19-Comparison of the actual carrying capacity with the carrying capacity estimated from the type of vegetation present

\begin{tabular}{|c|c|c|c|c|}
\hline \multirow{2}{*}{$\begin{array}{l}\text { Area } \\
\text { No. }\end{array}$} & \multirow{2}{*}{$\begin{array}{l}\text { Counties } \\
\text { mainly } \\
\text { represented } \\
\text { in area }\end{array}$} & \multirow{2}{*}{$\begin{array}{l}\text { Number } \\
\text { of farms* }\end{array}$} & \multicolumn{2}{|c|}{$\begin{array}{c}\text { Average carrying capacity } \\
\text { per farm }\end{array}$} \\
\hline & & & $\begin{array}{c}\text { Found } \\
\text { (animal units) }\end{array}$ & $\begin{array}{l}\text { Calculated } \\
\text { (animal units) }\end{array}$ \\
\hline 1 & Jackson & 17 & 17.5 & 15.2 \\
\hline 2 & Ritchie & $2 S$ & 20.2 & 18.5 \\
\hline 3 & Monongalia & 14 & 19.2 & 16.2 \\
\hline 4 & Harrison & 39 & 22.9 & 26.3 \\
\hline 5 & Marshall & 26 & 22.7 & 25.8 \\
\hline 6 & $\begin{array}{l}\text { Pendleton } \\
\text { Hardy } \\
\end{array}$ & 20 & 22.3 & 25.2 \\
\hline 7 & $\begin{array}{l}\text { Pandolph } \\
\text { Pocahontas }\end{array}$ & 26 & 43.5 & 45.6 \\
\hline 8 & $\begin{array}{l}\text { Monroe } \\
\text { Greenbrier }\end{array}$ & 20 & 32.3 & 36.3 \\
\hline 9 & $\begin{array}{l}\text { Jefferson } \\
\text { Berkeley }\end{array}$ & 16 & 21.8 & 23.1 \\
\hline Ave & ze (weighted) & $\begin{array}{l}206 \\
(\text { Total) }\end{array}$ & 25.0 & $25 . S$ \\
\hline
\end{tabular}

*Those farms were omitted where Iess than one-half of the summer feed was supplied by the non-woodland pastures surveyed. 
is very low in available phosphorus, and only $3 \%$ has 20 pounds or more of available phosphorus per aere. In contrast, $31 \%$ of the soils of the good and excellent pastures have this larger amount of availahle phosphorus.

The relatively high percentage of good and excellent pastures that have soils of less than 20 pounds available phosphorus is at first thought somewhat surprising. Part of the explanation for these results probably lies in the faet that some soils high in organie matter ean support a good sod at relatively low levels of available inorganic phosphorus (as measured by the Truog method). Likewise, the faet that good pastures are found on some soils below pH 5.8 is partly explained by the relatively high pereentage-base saturation found in soils containing a high eontent of organie matter. $\dagger$ The more important explanation for these apparent discrepancies, however, is that some of the desirable speeies are able to grow on soils of more acid reaction and of lower eontent of available

\section{Table 20-Classification of open pastures on the basis of vegetation}

\begin{tabular}{|c|c|c|c|c|c|c|}
\hline \multirow{2}{*}{$\begin{array}{l}\text { Area } \\
\text { No. }\end{array}$} & \multirow{2}{*}{$\begin{array}{l}\text { Counties } \\
\text { mainly } \\
\text { represented } \\
\text { in area }\end{array}$} & \multicolumn{5}{|c|}{ Percentage of pasture acreage in each class* } \\
\hline & & Poor & Fair & Medium & Good & Excellent \\
\hline 1 & Jackson & 77 & 11 & $s$ & 4 & $<1$ \\
\hline 2 & Ritchie & 79 & 19 & 1 & 1 & $<1$ \\
\hline 3 & Monongalia & 53 & 29 & 18 & $<1$ & $<1$ \\
\hline 4 & Harrison & 67 & 13 & 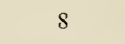 & 12 & $<1$ \\
\hline 5 & Marshall & 14 & 16 & 41 & 28 & $<1$ \\
\hline 6 & $\begin{array}{l}\text { Pendleton } \\
\text { FIardy }\end{array}$ & 48 & 17 & 25 & 10 & $<1$ \\
\hline 7 & $\begin{array}{l}\text { Randolph } \\
\text { Pocahontas }\end{array}$ & 49 & 21 & $2 S$ & 2 & $<1$ \\
\hline 8 & $\begin{array}{l}\text { Monroe } \\
\text { Greenbrier }\end{array}$ & 15 & 41 & 25 & 1s & $<1$ \\
\hline 9 & $\begin{array}{l}\text { Jefferson } \\
\text { Berkeley }\end{array}$ & 14 & s & 37 & 30 & 11 \\
\hline Aver & se (weightod) & 50 & 20 & 19 & 10 & 1 \\
\hline
\end{tabular}

*Poor $=0-15 \%$ desirable spceies

Fair $\quad=16-30 \%$ desirable species

Mediun $=31.50 \%$ desirable species

Good $=51.75 \%$ desirable species

Excellent $=76-100 \%$ desirable species

See Table 18 for more complete description of standards.

$\leftarrow$ Robinson, R. R. Soil Properties Determining the Botanical Composition of Pastures in West Virginia. Jour. Agr. Res. Vol. 54, No. 12, 1937. 
phosphorus than others. It is well known, for example, that redtop and especially Common lespedeza ean maintain themselves on poorer and more acid soils than Kentucky bluegrass and white elover.

\section{General Conclusions and Recommendations}

The data obtained in this investigation show that many of the permanent pastures of West Virginia require 5 or 6 acres to pasture one animal unit. This low earrying capacity is found to be due to the poor type of vegetation present. Kentucky bluegrass and white clover, which once were abundant in permanent pastures, are in many areas now found only in very small amounts, the average in all the pastures studied being slightly less than 15 percent of a perfeet stand. In the place of these desirable pasture plants have eome the poor native grasses and weeds, plants which produee poor vields and herbage of low palatability or poor quality. Moreover, the sod has become thinner and soil erosion has been taking place at increasing rates.

These conditions have, of course, been developing for a number of years. As the results show, very little attention has been given by farm-

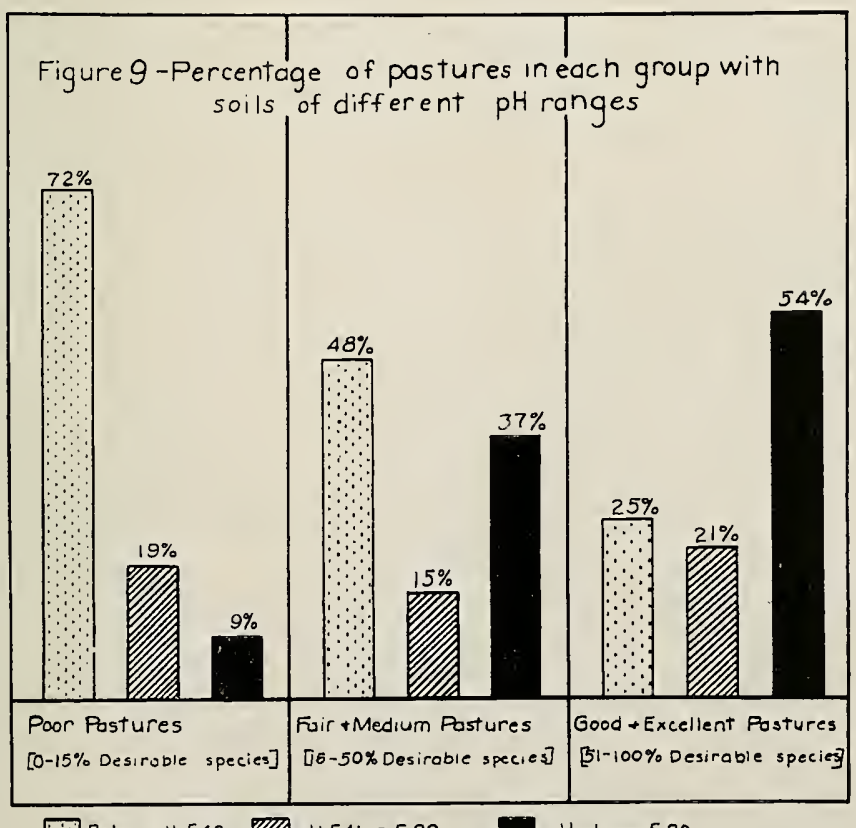

Below pH 5.40 WIAPH $5.41-5.80$

$\mathrm{pH}$ above 5.80

[includes only the soils with more than 10los. readily ovailable phosphorus] 
ers to pasture improvement work. Some farmers believe that the several dry seasons experienced since 1930 are the main cause of our present pasture conditions and that as soon as we have a few normal or wet years the bluegrass and elover will come back. It is evident from the data obtained in this investigation, however, that even with the most favorable seasons, very little increase in desirable plants can be expected in most pastures unless something is done to improve the fertility of the soils.

The results of this investigation point to two main causes for the poor type of vegetation and low carrying capacity of many West Virginia pastures. These are:

\section{Soil acidity \\ Depleted soil fertility}

Lime is necded on at least $85 \%$ of the pasture soils before Kentucky bluegrass and white clover can be re-established. Moreover, there is an even greater need for phosphor'us. Ninety-four percent of the soils of the total pasture area studied was found to be very deficient in available

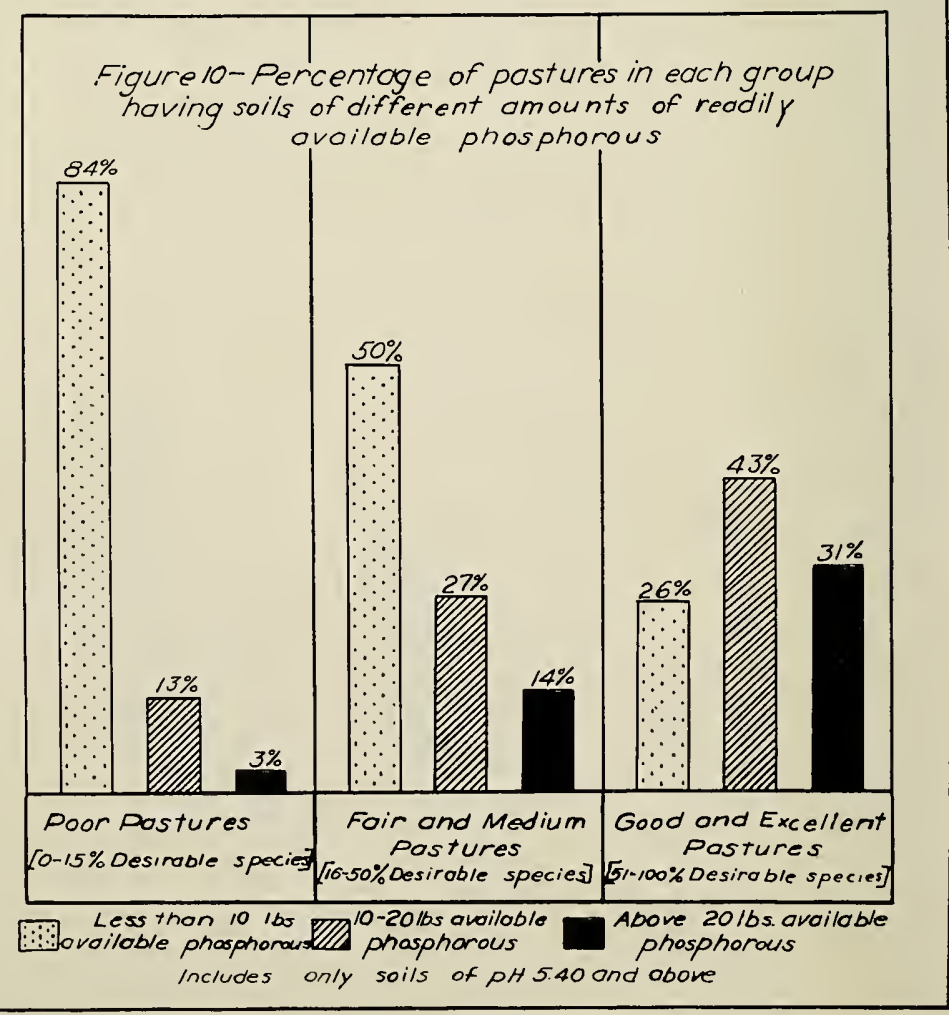


phosphorus. 'These results are not surprising when it is considered that lime and phosphorus are the main constituents of the animal skeleton. Through the sale of animals and of other farm products these elements have been continuously removed from the soils during the last 50 to 150 years and very little, if any, returned in the way of lime and superphosphate. Nitrogen is also deficient in many of the pasture soils. Through the use of lime and superphosphate, however, white clover and other legumes will be encouraged and these leguminous plants will help to supply the nitrogen required by the grasses.

Experimental work conducted at this Station and at other stations shows that top dressings of lime and superphosphate will bring back a good stand of bluegrass and other desirable plants on many pastures. Not all pastures, however, can be improved eronomically. On the basis of the present investigation it is concluded that at least one-third of the pasture acreage in the state is either so steep or so badly eroded that it cannot be improved economically. In some of the steeper and poorer pasture sections the percentage of the area that is not suitab]e for improvement amounts to over $50 \%$. These areas furnish very little. herbage and should be returned to woodland. By so doing the soils would be better protected flom further erosion, and in future years the timber from such wooded slopes would doubtless yield a greater return than is now obtained from the pastures.

The pastures that will respond most profitably to the use of lime and superphosphate are in general those that are on the more gentle slopes and are not droughty or badly eroded. In the poorer pasture sections of the state these conditions will usually be found on only the better pastures of the farm.

The main benefits that result from the use of lime and superphosphate on pastures come about because of the fact that the percentage of bluegrass and other desirable plants is increased and the percentage of poor native grasses and weeds decreased. As shown in this study, the carrying capacity of a pasture or the number of acres required to pasture an animal unit is largely determined by the percentage of desirable species in the pasture. As this percentage increases, the carrying capacity of the pasture increases. The reason for this close relationship is easily seen. Bluegrass and other desirable plants start growth earlier in the spring than do poverty grass and other native grasses. Moreover, ther yield more per acre and produce herbage that is more palatable and more nutritious to the grazing animal. Pastures that are improved by moderate applications of lime and superphosphate, therefore, will often carry twice as many animals after treatment as before treatment. The thicker, heavier sod which develops will also reduce erosion to a minimum even on relatively steep slopes.

In addition to the use of lime and superphosphate, much can be done toward improving permanent pastures by following better management practices. As discussed on pages 25 to 28 , the most serious weaknesses of the present practices are : (1) winter grazing, (2) turning cattle on pastule too early in the spring or before there is much growth, 
and (3) failure to mow weeds and coarse, mature vegetation. Under no condition obtaining in West Virginia can the practice of forcing animals to obtain all their winter feed from pastures be justified. Likewise, the turning of cattle on pasture early in the spring, when the grass is just starting growth, is harmful to the growth of the vegctation during the remainder of the scason.

The data obtained in this investigation lead to the conclusion that a new attitude toward permanent pastures is neccssary before much improvement can be expected. Pastures should be recognized as the most important crop in West Virginia and as such should receive the attention that the crop deserves. Not all land is good enough for pastures. Like any other crop, pastures will produce in direct proportion to the fertility of the soil.

The problem of pasture improvement is one that challenges the best efforts of all those interested in the welfare of West Virginia agriculture. West Virginia is a livestock state primarily because of the large pasture acreage. If the pastures of the state are allowed to fail, the livestock industry of the state must likewise fail. 


\section{Appendix}
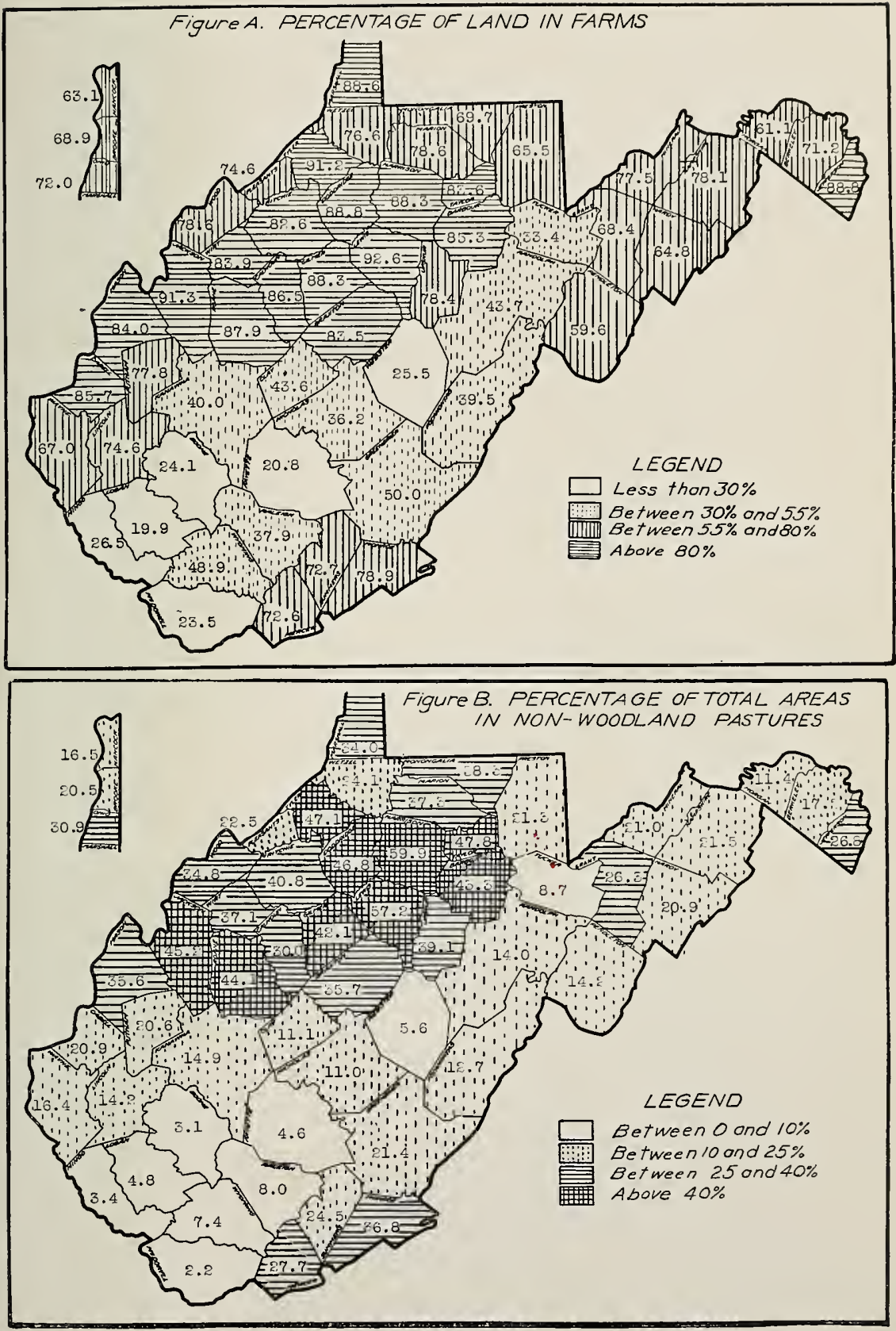


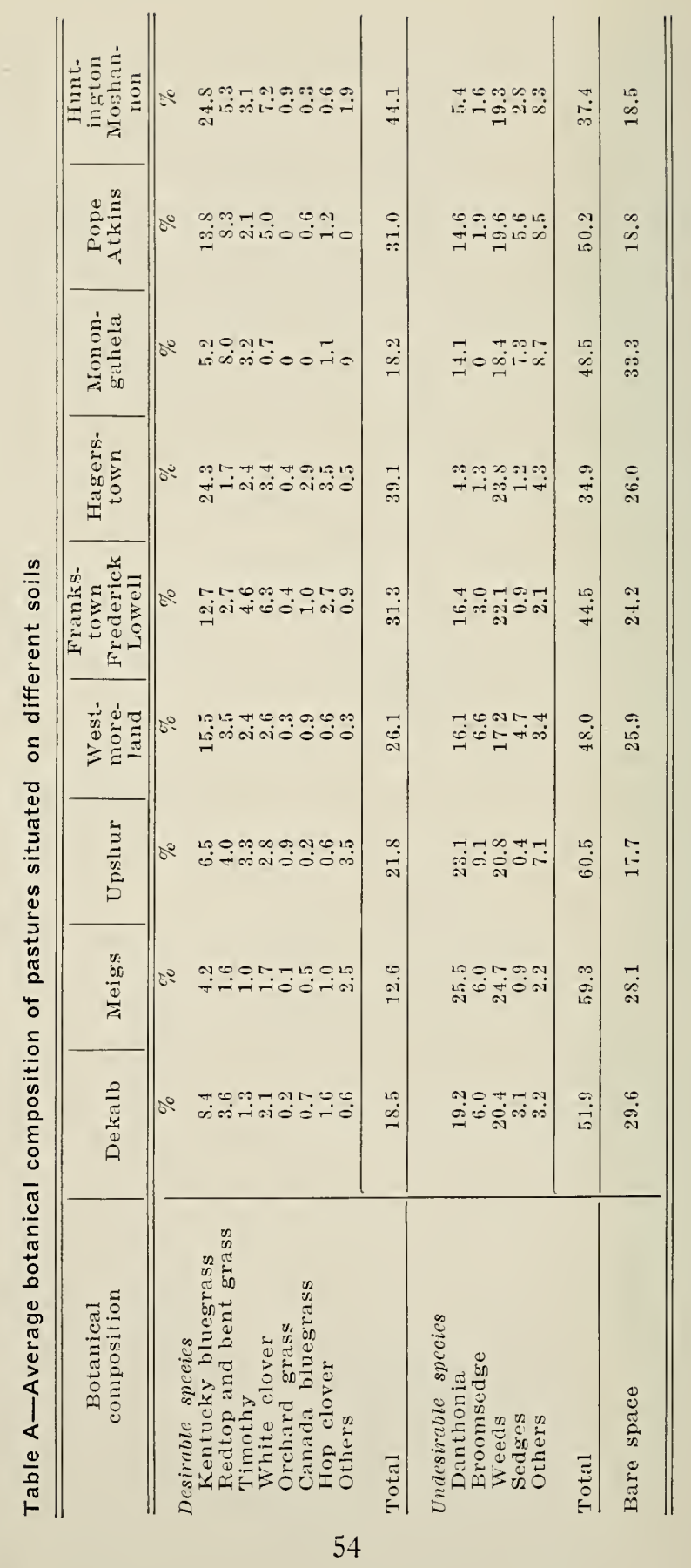


Table B-Percentage distribution of available phosphorus and acidity of soils by soil series

\begin{tabular}{|c|c|c|c|c|c|c|c|}
\hline \multirow{2}{*}{$\begin{array}{l}\text { Soil } \\
\text { series }\end{array}$} & \multicolumn{3}{|c|}{$\begin{array}{l}\text { \% of total acreage in various } \\
\text { "available phosphorus classes" }\end{array}$} & \multicolumn{4}{|c|}{$\begin{array}{c}\text { \% of total acreage in various } \\
\text { pH classes }\end{array}$} \\
\hline & $\begin{array}{l}\text { Tess } \\
\text { than } \\
101 \mathrm{~b} \text {. }\end{array}$ & $\begin{array}{c}10 \text { to } 20 \\
1 \mathrm{~b} .\end{array}$ & $\begin{array}{l}\text { Above } \\
20 \mathrm{lb} \text {. }\end{array}$ & $\begin{array}{l}\text { Felow } \\
\text { p!1 } 5.0\end{array}$ & $\begin{array}{c}\mathrm{pH} \\
5.0-5.4\end{array}$ & $\begin{array}{c}\text { pH } \\
5.4-5.8\end{array}$ & $\begin{array}{l}\text { pH } \\
\text { above } \\
5.8\end{array}$ \\
\hline Dekalb & 71.4 & 18.2 & 10.4 & 13.2 & 43.9 & 26.7 & 16.2 \\
\hline Meigs & 93.2 & 6.2 & 0.6 & 11.5 & 52.0 & 31.0 & 2.5 \\
\hline Upshur & 88.2 & 11.8 & 0 & 12.0 & 40.9 & 45.5 & 1.6 \\
\hline Westmoreland & 60.0 & 32.6 & 7.4 & 24.7 & 52.7 & 14.3 & 8.3 \\
\hline $\begin{array}{l}\text { Frankstown } \\
\text { Frederick } \\
\text { Lowell }\end{array}$ & 82.0 & 15.9 & 2,1 & 0.9 & 33.8 & 45.2 & 20.1 \\
\hline Hagerstown & 61.3 & 29.6 & 9.1 & 0 & 22.9 & 9.4 & 67.7 \\
\hline Monongahela & 63.4 & 36.6 & 0 & 24.4 & 55.3 & 0 & 20.3 \\
\hline $\begin{array}{l}\text { Pope } \\
\text { Atkins }\end{array}$ & 66.9 & 15.7 & 17.4 & 39.6 & 12.2 & 27.3 & 20.9 \\
\hline $\begin{array}{l}\text { Huntington } \\
\text { Moshannon }\end{array}$ & 57.5 & 22.8 & 19.7 & $23 . ?$ & 25.7 & $\mathbf{i} 5.4$ & 35.6 \\
\hline Misc. soils & 52.6 & 47.4 & 0 & 0 & 52.6 & 5.3 & 42.1 \\
\hline
\end{tabular}

\section{Table C-Slope and erosion data for different soils}

\begin{tabular}{|c|c|c|c|c|c|c|c|}
\hline \multirow{2}{*}{$\begin{array}{l}\text { Soil } \\
\text { series }\end{array}$} & \multicolumn{3}{|c|}{$\begin{array}{c}\text { \% of area in different } \\
\text { slope classes }\end{array}$} & \multicolumn{4}{|c|}{$\begin{array}{c}\% \text { of area in different erosion } \\
\text { classts }\end{array}$} \\
\hline & $\begin{array}{l}0-25 \% \\
\text { slope }\end{array}$ & $\begin{array}{l}25-40 \% \\
\text { slope }\end{array}$ & $\begin{array}{l}\text { Over } \\
40 \% \\
\text { slope }\end{array}$ & $\mid \begin{array}{c}\text { No } \\
\text { erosion }\end{array}$ & $\begin{array}{l}\text { Slight } \\
\text { erosion }\end{array}$ & $\begin{array}{l}\text { Medium } \\
\text { erosion }\end{array}$ & $\begin{array}{l}\text { Higl } \\
\text { erosion }\end{array}$ \\
\hline Dekalb & 39.1 & 42.2 & 18.7 & 0.2 & 3.7 & 75.6 & 20.5 \\
\hline$\overline{\mathrm{Meigs}}$ & 26.7 & 38.0 & $3 \overline{5.3}$ & 1.0 & 3.0 & 53.0 & 43.0 \\
\hline Upshur & 52.0 & 33.9 & 14.1 & 0 & 15.8 & 75.4 & 8.8 \\
\hline $\begin{array}{l}\text { Westmore- } \\
\quad l i n d \\
\end{array}$ & 42.2 & 43.0 & 14.8 & 0.3 & 11.2 & 73.4 & 15.1 \\
\hline $\begin{array}{l}\text { Frankstown } \\
\text { Frederick } \\
\text { Lowell }\end{array}$ & 74.7 & 20.7 & 4.6 & 0.7 & 18.9 & 76.1 & 4.3 \\
\hline Hagerstown & 88.6 & 9.4 & 2.0 & 3.0 & 11.6 & 78.0 & 7.4 \\
\hline Monongahela & 100.0 & 0 & 0 & 63.2 & 7.0 & 29.8 & 0 \\
\hline $\begin{array}{l}\text { Pope and } \\
\text { Atkins }\end{array}$ & 100.0 & 0 & uे & 100.0 & 0 & 0 & 0 \\
\hline $\begin{array}{l}\text { Huntington } \\
\text { Moshannon }\end{array}$ & 100.0 & 0 & 0 & 100.0 & 0 & 0 & 0 \\
\hline Misc. soils & 59.0 & 12.5 & 28.5 & 20.0 & 22.0 & 58.0 & 0 \\
\hline
\end{tabular}




\section{Abstract}

A comprehensive study of the conditions of permaneut pastures in West Virginia was started in 1935 in cooperation with the Soil Conservation Service and the Bureau of Plant Industry of the United States Department of Agriculture. A total of 775 pastures in nine important pastmre areas of the state, comprising parts of 20 counties, were examined as to the kind and amount of vegetation, the soil type, depth of surface soil, amount of erosion, and degree of slope. A total of 764 soil samples were taken, and determinations made of available phosphorus and soil acidity. In addition, data were obtained on pasture management and on the carrying capacity of the pastures.

In the poorest of the nine areas an average of 5.3 acres of nonwoodland pasture was required to pasture one animal unit, whereas in the best area an average of 2.5 acres was sufficient. The wide differences in carrying capacity among different areas and among individual pastures were found to be closely related to the type of vegetation present. In the area of lowest carrying: capacity less than $11 \%$ of the pasture sod was made up of desirable grasses and legumes, whereas in the best area the value was $47 \%$.

On the basis of the close relationship found between the type of vegetation and carrying capacity, a standard was developed by which the carrying capacity of a permanent pasture can be estimated from a knowledge of the desirable species present in the vegetation.

The most important factors responsible for poor type of vegetation were soil acidity and lack of available phosphorus. Of the total area studied, $85 \%$ was found to be in need of lime, and $94 \%$ deficient in available phosphorus. Associated with these two factors in affecting the type of vegetation were soil type, degree of slope, and soil erosion.

The principal soil series, ranked in increasing order as regards the percentage of desirable species in the pastures, are as follows: Meigs, Dekalb, Upshur, Westmoreland, Pope, Franisstown, Hagerstown, and Huntington.

On the basis of various soil factors, particularly slope and erosion, it was estimated that $25 \%$ of the pasture area studied conld not be improved economically but should be returned to woods. 
. 
